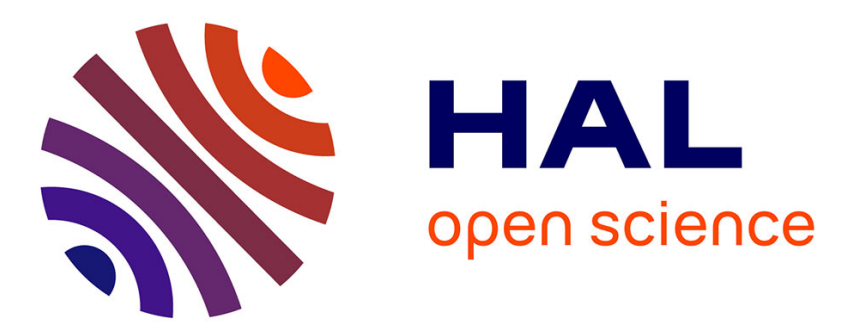

\title{
Structure, Energetics, and Dynamics of Smectite Clay Interlayer Hydration: Molecular Dynamics and Metadynamics Investigation of Na-Hectorite
} C.P. Morrow, A.O. Yazaydin, M. Krishnan, G.M. Bowers, Andrey G. Kalinichev, R.J. Kirkpatrick

\section{To cite this version:}

C.P. Morrow, A.O. Yazaydin, M. Krishnan, G.M. Bowers, Andrey G. Kalinichev, et al.. Structure, Energetics, and Dynamics of Smectite Clay Interlayer Hydration: Molecular Dynamics and Metadynamics Investigation of Na-Hectorite. Journal of Physical Chemistry C, 2013, 117, pp.5172-5187. 10.1021/jp312286g · in2p3-00870391

\section{HAL Id: in2p3-00870391 https://hal.in2p3.fr/in2p3-00870391}

Submitted on 6 Nov 2018

HAL is a multi-disciplinary open access archive for the deposit and dissemination of scientific research documents, whether they are published or not. The documents may come from teaching and research institutions in France or abroad, or from public or private research centers.
L'archive ouverte pluridisciplinaire HAL, est destinée au dépôt et à la diffusion de documents scientifiques de niveau recherche, publiés ou non, émanant des établissements d'enseignement et de recherche français ou étrangers, des laboratoires publics ou privés. 


\title{
Structure, Energetics, and Dynamics of Smectite Clay Interlayer Hydration: Molecular Dynamics and Metadynamics Investigation of Na-Hectorite
}

\author{
Christin P. Morrow, ${ }^{1}$ A. Özgür Yazaydin, ${ }^{1,2}$ Marimuthu Krishnan, ${ }^{1,3}$ Geoffrey M. Bowers, ${ }^{4,5}$ \\ Andrey G. Kalinichev, ${ }^{1,6}$ and R. James Kirkpatrick ${ }^{7, *}$ \\ ${ }^{1}$ Department of Chemistry, Michigan State University, East Lansing, MI USA 48824 \\ ${ }^{2}$ Department of Chemical Engineering, University of Surrey, Guildford, UK GU2 7XH \\ ${ }^{3}$ Center for Computational Natural Sciences and Bioinformatics, International Institute of \\ Information Technology, Gachibowli, Hyderabad India 500032 \\ ${ }^{4}$ Division of Chemistry, Alfred University, Alfred, NY USA 14802 \\ ${ }^{5}$ Department of Materials Engineering, Alfred University, Alfred, NY USA 14802
}

${ }^{6}$ Laboratoire SUBATECH, École des Mines de Nantes, Nantes Cedex 3, France 44307

${ }^{7}$ College of Natural Sciences, Michigan State University, East Lansing, MI USA 48824

*corresponding author: rijkirk@cns.msu.edu 


\section{Abstract}

The structure and dynamics of the interlayer galleries of clay materials are difficult to investigate experimentally due to static and dynamic disorder, and computational methods can provide important and otherwise unobtainable insight. This paper presents a classical molecular dynamics (MD) and metadynamics investigation of the relationships between the structure, energetics, and dynamics of Na-hydroxyhectorite, a swelling (smectite) clay and tests the predictions of a model for interlayer $\mathrm{H}_{2} \mathrm{O}$ structure and dynamics for a natural mixed fluoro/hydroxyl-hectorite based on ${ }^{2} \mathrm{H}$ NMR spectroscopy [Bowers, G. M.; Singer, J. W.; Bish, D. L.; Kirkpatrick, R. J. J. Phys. Chem. C 2011, 115, 23395]. The computational and experimental results are in good agreement and indicate that water molecules undergo simultaneous fast librational motions about the $\mathrm{H}_{2} \mathrm{O} \mathrm{C}_{2}$ symmetry axis and site hopping with $\mathrm{C}_{3}$ symmetry with respect to the surface normal. The computed hydration energies show the stability of one-, one-and-one-half-, and two-water-layer hydrates, which for the composition modeled occur at $3,5.5$, and $10 \mathrm{H}_{2} \mathrm{O} / \mathrm{Na}^{+}$, respectively. The nearest neighbor coordination of $\mathrm{Na}^{+}$ is entirely by the basal oxygen atoms of the tetrahedral sheet $\left(\mathrm{O}_{\mathrm{MIN}}\right)$ at the lowest hydration levels, and with increasing water content includes increasing numbers of water molecules $\left(\mathrm{O}_{\mathrm{H} 2 \mathrm{O}}\right)$. For the two-layer hydrate, $\mathrm{Na}^{+}$is entirely coordinated by six $\mathrm{O}_{\mathrm{H} 2 \mathrm{O}}$. The dipole moment of $\mathrm{H}_{2} \mathrm{O}$ molecules is oriented nearly perpendicular with respect to the clay surface in the one-layer hydrate, whereas the dipoles are oriented at lower angles in the two-layer hydrate, where the $\mathrm{H}_{2} \mathrm{O}$ donates on average one hydrogen bond to surface $\mathrm{O}$ atoms. The H-bonding network becomes more integrated with increasing hydration, with a maximum of three $\mathrm{H}$-bonds per interlayer $\mathrm{H}_{2} \mathrm{O}$ molecule. The metadynamics results yield activation energies for site hopping of $\mathrm{H}_{2} \mathrm{O}$ molecules $\sim 6.0 \mathrm{~kJ} / \mathrm{mol}$ for the one-layer structure and $\sim 3.3 \mathrm{~kJ} / \mathrm{mol}$ for hopping between layers in the two- 
layer structure. Computed diffusion coefficients for water and $\mathrm{Na}^{+}$are substantially less than in bulk liquid water, as expected in a nano-confined environment and are in good agreement with previous experimental and computational results. 


\section{Introduction}

Molecular-scale physicochemical processes occurring at mineral-water interfaces are immediately pertinent to many geochemical, technological, and environmental issues such as stabilization of carbon in soils, ${ }^{1-3}$ deep geological $\mathrm{CO}_{2}$ storage, ${ }^{4-8}$ nutrient cycling and reactive transport, $^{9-14}$ and long-term nuclear waste disposal in geological formations. ${ }^{15-17}$ At the heart of these issues is the need to understand the structure, energetics, and dynamics of ions and water molecules at mineral-water interfaces over time scales from picoseconds (ps) to millennia and length scales from Ångstroms to kilometers. Fundamental chemical processes, such as swelling of clay layers and diffusion of aqueous species, occur on timescales of ps to ms, and computational modeling ${ }^{18-38}$ and spectroscopic methods such as nuclear magnetic resonance (NMR) spectroscopy ${ }^{39-46}$ and neutron scattering have proven to be especially effective tools for interrogating these behaviors. ${ }^{47-67}$ This paper describes a computational molecular dynamics (MD) and metadynamics modeling study of the interaction of $\mathrm{Na}^{+}$and $\mathrm{H}_{2} \mathrm{O}$ molecules with the clay mineral hectorite (a smectite) that provides new insight into the structure, energetics, and dynamics of these interactions and complements our previous ${ }^{2} \mathrm{H}$ and ${ }^{23} \mathrm{Na} \mathrm{NMR}$ study of this material. $^{46}$

Interaction of water and ions with swelling clays occurs in the interlayer galleries between the silicate sheets (Figure 1) and on external surfaces of individual particles in the interparticle regime. ${ }^{68,69}$ The interlayer galleries permit intercalation of water molecules, ${ }^{44-}$ 46,57,58,60,64,65,67 organic and bio-molecules, ${ }^{70,71}$ as well as organic ${ }^{72,73}$ and inorganic ions. ${ }^{72,74}$ For many clays, the interlayer species cause the clay to swell, but the molecular-scale details of the interlayer structure, energetics, and dynamics are still not completely understood. For instance, X-ray diffraction, neutron scattering and NMR spectroscopy data indicate water molecules in 
smectite interlayers form one- and two-layer hydrates. ${ }^{44-46,57,58,60,64,65,67}$ Structurally, the effects of changing hydration levels on the orientation of water molecules with respect to the surface, coordination of the cations by $\mathrm{H}_{2} \mathrm{O}$ and the $\mathrm{O}$ atoms of the basal clay surface, location of the cations and $\mathrm{H}_{2} \mathrm{O}$ molecules with respect to the $\mathrm{Si}-\mathrm{O}$ hexagonal rings of the silicate layers, and structure of the H-bonding network, and the energetics of site hopping and water libration or rotation are open questions that benefit directly from the type of molecular-scale insight provided by classical MD simulations. ${ }^{44-46,57,58,60,64,65,67}$

Current understanding indicates that the energetics of clay swelling reflects a tradeoff between attractive and repulsive forces involving the charged mineral surfaces, the interlayer cations/anions, and $\mathrm{H}_{2} \mathrm{O}$ molecules. The electrostatic components of these forces stem from the interaction between charged clay sheets and charge-balancing interlayer and surface ions, ${ }^{68}$ the formation of hydrogen bonds (HBs) between water molecules in the interlayer with clay atoms and one another, and the hydration of charge-balancing ions. ${ }^{21,36,75-79}$ The most important nonelectrostatic component of the forces balancing the electrostatic attraction is the van der Waalstype repulsive interactions at short intermolecular distances due to the finite size of the atoms and the "excluded volume" effect pertinent to any nano-confined fluid (e. g. Abraham 1978). ${ }^{80}$ For a given clay composition at relatively low $\mathrm{H}_{2} \mathrm{O}$ activities, hydration of the charge-balancing counter ions is the dominant interaction leading to swelling, and differences in swelling behavior are directly related to the differences in the cation hydration energy. ${ }^{75-77,81}$

Previous experimental studies of hectorite swelling and its interactions with cations and water molecules have used a variety of techniques, including X-ray diffraction (XRD), ${ }^{46,82-91}$ thermogravimetric analysis (TGA), ${ }^{40,46,91}$ quasi-elastic neutron scattering (QENS), ${ }^{57,58,60,64,65,67}$ and NMR spectroscopy. ${ }^{39,40,42,44-46}$ XRD is widely used and provides information about the 
effects of, for instance, relative humidity on the interlayer spacing., ${ }^{42,43,46,92-94}$ Due to static and dynamic disorder in the interlayer, XRD typically does not provide the specific atomic positions needed for detailed structural analyses, particularly with respect to the hydrogen positions, and provides essentially no information about dynamics. NMR spectroscopy can be used to study both structure and dynamics of both interlayer ions and $\mathrm{H}_{2} \mathrm{O}$ and has been used extensively to study hectorite because samples with low Fe-content are readily available. Our previous NMR studies have used ${ }^{23} \mathrm{Na},{ }^{39} \mathrm{~K}$, and ${ }^{133} \mathrm{Cs}$ to investigate the structural and dynamical behavior of the cations and ${ }^{2} \mathrm{H}$ NMR to probe the water structure and dynamics at a variety of system $\mathrm{H}_{2} \mathrm{O}$ contents. ${ }^{39,40,42,46}$ In our recent work, we have proposed a mechanistic description of the librational and site hopping motion of $\mathrm{H}_{2} \mathrm{O}$ molecules in two-layer hectorite hydrates between $80^{\circ} \mathrm{C}$ and $50^{\circ} \mathrm{C}$ and hectorite pastes from $-50^{\circ} \mathrm{C}$ to $-20^{\circ} \mathrm{C}$ based on ${ }^{2} \mathrm{H}$ NMR results. ${ }^{46}$ This mechanism suggests that $\mathrm{H}_{2} \mathrm{O}$ molecules undergo fast librational motions about the $\mathrm{H}_{2} \mathrm{O} \mathrm{C}_{2}$ symmetry axis and site hopping with $\mathrm{C}_{3}$ symmetry with respect to the surface normal. One objective of the present study is use of computational modeling to evaluate this $\mathrm{C}_{2} / \mathrm{C}_{3}$ hopping mechanism.

Neutron scattering also probes interlayer structure and $\mathrm{H}_{2} \mathrm{O}$ diffusion, and there have been several recent studies of interlayer water diffusion in smectites using this technique. ${ }^{57,58,60,64,65,67}$ Unfortunately, neutron scattering techniques have difficulty distinguishing between the $\mathrm{H}$ atoms of interlayer $\mathrm{H}_{2} \mathrm{O}$ molecules and those of structural $\mathrm{OH}^{-}$groups, and structural $\mathrm{OH}^{-}$groups contribute background noise and complicate data analysis. ${ }^{55,57,65}$ Thus, QENS has been used only for fluorhectorites, in which $\mathrm{F}^{-}$substitutes fully for structural $\mathrm{OH}^{-}$ $, 57,58,60,64,65,67$ whereas natural hectorites often contain nearly equal mixtures of structural $\mathrm{OH}^{-}$ and $\mathrm{F}^{-}$. 
The computational MD methods we use can readily model systems with length scales of nm over timescales of several ns and have been effectively applied to many mineral-water systems ${ }^{20,21,24,27,31-33,35,36,95}$ including fluorhectorite. ${ }^{67}$ Computational investigations of layered material hydration have focused on montmorillonite ${ }^{18,19,23,25,51,55,65,69,75-77,96-117}$ beidelite, ${ }^{102,109,113}$ hectorite, ${ }^{65,67,72,102,109,118} \quad$ illite $^{118}$ kaolinite, ${ }^{69,118}$ muscovite, ${ }^{31,32,35,119}$ pyrophyllite, ${ }^{120}$ saponite, ${ }^{121,122}$ talc, ${ }^{26,30,32,35}$ vermiculite, ${ }^{97,118}$ and layered double hydroxides (LDHs), ${ }^{21,24,25,27,32,36,78,79}$ For swelling clays (smectites), these studies find that the interlayer spacing increases with increasing total system $\mathrm{H}_{2} \mathrm{O}$ content, $\mathrm{H}_{2} \mathrm{O}$ molecules organize into discreet layers in the interlayer galleries until reaching the osmotic swelling regime, the orientation of cations and $\mathrm{H}_{2} \mathrm{O}$ molecules with respect to the clay surface changes with hydration, and the interlayer cation and $\mathrm{H}_{2} \mathrm{O}$ diffusion rates are slower than in bulk water by at least an order of magnitude.

The identification and characterization of stable hydration states such as one- (1 WL) and two-water-layer (2 WL) hydrates in computational studies involves use of many parameters including interlayer spacing, ${ }^{18,19,21,23,25,36,67,69,72,75,79,96,97,99-102,104-106,108-110,112,113,116,117,122,123 ~}$ water- $^{-}$ to-clay mass ratio, ${ }^{18,19,21,23,26,36,55,67,72,75,79,99,101,105,106,108-113,115-117,121-123 ~ i n t e r l a y e r ~ a t o m i c ~ d e n s i t y ~}$ profiles, ${ }^{18,19,23,26,27,30-32,35,36,51,75,77,79,97,100,101,104,105,109,110,112-116,120,122}$ and hydration energy of the clay/water system versus the anhydrous system. ${ }^{18,19,21,23,31,32,36,76-79,96,97,99,102,103,106,107,110,113,123 ~}$ For smectites, 1 WL hydrates typically have 3 - $7 \mathrm{H}_{2} \mathrm{O}$ molecules per interlayer cation $\left(\mathrm{H}_{2} \mathrm{O} /\right.$ cation), and 2 WL hydrates have 7-13 $\mathrm{H}_{2} \mathrm{O}$ /cation, depending on the number of cations/formula unit needed for electrostatic charge neutrality. ${ }^{18,55,65,67,72,75,97-99,101,104,111,116,118,122}$ Analysis of the nearest neighbor coordination environments of the cations, the interlayer hydrogen bonding network, and the orientation of $\mathrm{H}_{2} \mathrm{O}$ molecules and other intercalated species with respect to the 
clay surface allow for description of the effect of water loading level has on the structure of species in the interlayer galleries. ${ }^{19,23,24,26,27,31,32,35,36,51,72,77-79,97-101,104,106-116,118-122}$

Dynamical analyses typically focus on the mean square displacement of water molecules and cations, ${ }^{51,67,101,107,108,113}$ characterization of their diffusional mobility, ${ }^{30-32,51,55,65,67,100-}$ $102,104,108,112,113$ and the evolution in the interlayer atomic positions with respect to the clay surface with time through use of atomic density contour plots. ${ }^{26,27,30-32,51,65,67,79,101,102,104}$ These studies indicate that diffusion of species increases with increasing hydration and that movement of $\mathrm{H}_{2} \mathrm{O}$ molecules and cations with time is dependent upon both the surface structure and the identity of the cation. Comparisons of $\mathrm{Li}^{+}, \mathrm{Na}^{+}$, and $\mathrm{K}^{+}$hydration in tetrahedrally- or octahedrallysubstituted clays suggest that $\mathrm{Na}^{+}$prefers to be outer-sphere coordinated in the interlayers of clays with octahedral substitutions while cations with lower charge density often prefer innersphere coordinations with the clay surface. ${ }^{114}$ Investigations of pressure and temperature effects on the mechanical properties ${ }^{119}$ and hydration of clays ${ }^{26,30,69,100,104,117}$ show interlayer compression and ensuing shortening of $\mathrm{HBs}$ between structural $\mathrm{OH}^{-}$groups and basal $\mathrm{O}$ atoms as well as increases in dynamical parameters such $\mathrm{C}_{2}$ hopping and diffusion as pressure and temperature are increased.

Previous computational investigations of hectorite have focused on hydration of Cs-, K-, Li-, and Na-hydroxyhectorite; ${ }^{72,102,109,118}$ Na-fluorhectorite; ${ }^{67}$ and intercalation of a lanthanide organic complex into Na-hydroxyhectorite. ${ }^{72}$ Development of the $1 \mathrm{WL}$ hydrate is thought to occur at hydration levels between 3 and $5 \mathrm{H}_{2} \mathrm{O}$ per monovalent cation ${ }^{65,67,72,118}$ and the $2 \mathrm{WL}$ hydrate at $10-11 \mathrm{H}_{2} \mathrm{O}$ per monovalent interlayer cation, depending on the bulk clay composition. ${ }^{109}$ Interlayer spacings for the $1 \mathrm{WL}$ hydrate range from $11.83-12.5 \AA,{ }^{67,72}$ and for the $2 \mathrm{WL}$ hydrate are in the range of $15 \AA .^{109}$ Interlayer $\mathrm{Li}^{+}$is thought to be inner-sphere 
coordinated with respect to the clay surface, ${ }^{118}$ whereas $\mathrm{Na}^{+}$is outer-sphere coordinated. ${ }^{109,118}$ $\mathrm{Cs}^{+}$ions are thought to be located above and off to the side of the basal Si-O hexagonal rings. ${ }^{102}$ Na-OMIN distances were $2.43-2.61 \AA$ in a MD study of Na-hydroxyhectorite with $\mathrm{H}_{2} \mathrm{O} / \mathrm{Na}^{+}=$ $6 .^{72}$ The computed diffusion coefficients for $\mathrm{H}_{2} \mathrm{O}$ molecules in 1 WL Na-fluorhectorite are 2.71 $6.2 \times 10^{-10} \mathrm{~m}^{2} / \mathrm{s}^{67}$ These results also indicate that $\mathrm{Cs}^{+}$does not diffuse significantly at low water content. ${ }^{102}$ The positions of the water molecules and the sites among which they diffuse correlate with the structure of the hectorite surface ${ }^{67}$ Water molecules occur in reasonably well defined layers ${ }^{109}$ and donate one HB to the surface in the 2 WL hydrate. ${ }^{109}$

This paper discusses the results of new classical MD simulations and metadynamic calculations of free energy probing the compositional dependence of the energetics of hectorite hydration, which facilitate identification of stable hydrate structures, the relationship between the interlayer HB network and the hydration energetics, and on comparison of the computed librational and site hopping dynamics to the behavior predicted from our recent ${ }^{2} \mathrm{H}$ NMR experiments ${ }^{46}$. The present study is the first full examination of the effects of hydration state on the interlayer structure, energetics, and dynamics of Na-hydroxyhectorite. These results show excellent agreement with our previous experiments.

\section{Computational Methods}

\subsection{Structural Models}

Hectorite is a trioctahedral 2:1 smectite clay with two tetrahedral silicate layers on either side of an octahedral metal oxide layer containing $\mathrm{Li}^{+}$and $\mathrm{Mg}^{2+}$ (TOT structure). The TOT layers develop net negative structural charge by $\mathrm{Li}^{+}$for $\mathrm{Mg}^{2+}$ substitution. ${ }^{124}$ The Si-O tetrahedra are 
arranged in hexagonal rings, and in the sample we have used experimentally, there is little Al for Si substitution. ${ }^{40}$ The negative layer charge is compensated by charge-balancing cations such as $\mathrm{Na}^{+}$in the interlayer and on external surfaces. ${ }^{39,40,42,44-46,57,58,60,64,65,67,124}$

Our simulated hectorite model is based on the structure of Breu et al. ${ }^{124}$ with $\mathrm{Na}^{+}$as the counter ion and a $\mathrm{Li}^{+} / \mathrm{Mg}^{2+}$ ratio of $1 / 5$ to reflect the composition of the natural San Bernardino hectorite we have used in the experimental studies. ${ }^{39,40,42,46}$ The structural formula is $\mathrm{Na}\left(\mathrm{Mg}_{5} \mathrm{Li}\right) \mathrm{Si}_{8} \mathrm{O}_{20}(\mathrm{OH})_{4}$. For the simulations, the $\mathrm{Li}^{+}$atoms are regularly substituted for $\mathrm{Mg}^{2+}$ such that there is one $\mathrm{Li}^{+}$in each unit cell. There is no tetrahedral substitution for $\mathrm{Si}^{4+}$. All of the anion sites in the octahedral sheet are modeled as $\mathrm{OH}^{-}$sites. The San Bernadino hectorite contains both $\mathrm{OH}^{-}$and $\mathrm{F}^{-}, 39,40,46$ and the hydration of fluorhectorite has been studied previously. ${ }^{44,57,58,60,65,67}$ The present study examines the structure, energetics, and dynamics of Na-hydroxyhectorite interlayer hydration, with water loading levels varying widely from 0 to 12 $\mathrm{H}_{2} \mathrm{O} / \mathrm{Na}^{+}$.

The simulation cells consisted of 60 formula units in a $5 a \times 4 b \times 3 c$ arrangement. There are thus $20 \mathrm{Li}^{+}$ions per layer, and each unit cell has a (-1) charge. The initial, anhydrous supercell dimensions were $\sim 26 \AA \times 36 \AA \times 32 \AA$. Although hectorite has $C 2 / m$ symmetry, ${ }^{125}$ the geometry of the simulation supercell is reduced to $P 1$ to allow for full relaxation of all crystallographic parameters during simulations with the anisotropic NPT ensemble. Because of the offset of neighboring TOT layers in the $C 2 / m$ structure, the initial $\mathrm{Na}^{+}$positions were located above the center of a Si-O hexagonal ring on one side of the layer and off-center in a hexagonal ring on the opposite side of the interlayer.

To simulate interlayer expansion at varying hydration states, ${ }^{21,26,27,36,78,79}$ the model structures were prepared with $0-12$ water molecules per cation. In the computational models 
presented here, $\mathrm{H}_{2} \mathrm{O} / \mathrm{Na}^{+}=\mathrm{H}_{2} \mathrm{O}$ /unit cell, and $\mathrm{H}_{2} \mathrm{O} / \mathrm{Na}^{+}=\mathrm{H}_{2} \mathrm{O} / 8 \mathrm{Si}$. Figure 1 shows snapshots of some of these systems viewed parallel to the TOT layers down the $b$-axis.

\subsection{Simulation Details}

The interatomic interactions are treated with the CLAYFF force field, ${ }^{25}$ which has been widely employed to model hydrated oxide and hydroxide systems, ${ }^{20,24,27,30-}$ $36,67,78,79,95,107,112,116,122,126-134$ including fluorhectorite. ${ }^{67}$ Water molecules are described with the flexible version ${ }^{135}$ of the simple point charge (SPC) potential, ${ }^{136}$ which reproduces the bulk properties of water well. ${ }^{137-142}$ Simulations are performed in the DL_POLY Classic molecular dynamics simulation package. ${ }^{143,144}$

To model interlayer expansion, we first build a unit cell of hectorite using atomic positions published by Breu et al., ${ }^{124}$ with $\mathrm{Na}^{+}$replacing $\mathrm{Cs}^{+}$in our models. $\mathrm{H}_{2} \mathrm{O}$ molecules are added to the unit cell to meet the desired hydration level. For each model, the $c$-dimension of the unit cell was set to approximate the interlayer spacing of the hydration level to be modeled, with the initial $c$-dimension $0.2-1.0 \AA$ greater than the anticipated interlayer spacing. We then allowed the interlayer species to relax in a 10 ps simulation with all species except the $\mathrm{H}_{2} \mathrm{O}$ and $\mathrm{Na}^{+}$fixed. These runs use the $N V T$ ensemble and the Nosé-Hoover thermostat ${ }^{145}$ with a $100 \mathrm{fs}$ relaxation constant. The final configuration from these simulations was used as the initial configuration for longer simulations in the anisotropic NPT ensemble with the Nosé-Hoover thermostat and barostat, ${ }^{145}$ each with a 100 fs relaxation time. The pressure was $1 \mathrm{~atm}$. All atoms were permitted to move in these and all subsequent simulations for each system. These runs used 500 ps for system equilibration followed by a 500 ps production run. For the anhydrous system, there is no initial $10 \mathrm{ps} N V T$ relaxation run. To ensure consistent statistics between samples with 
varying hydration levels and the absence of rotational movement of the simulation cell, ${ }^{146}$ a final NVT simulation was performed for all systems starting with the final configurations from the $N P T$ simulations. The $N V T$ ensemble employs the same procedures described above, except that the total simulation time was $1 \mathrm{~ns}$, with 500 ps equilibration followed by a 500 ps production run. The majority of results presented here are from these final 100 ps of the NVT simulations. Interlayer spacing results are from the final $100 \mathrm{ps}$ of the NPT simulations for each hydration level, and the diffusion coefficients and atomic positions results are from the whole trajectory of the 1 ns $N V T$ simulation. For all simulations, periodic boundary conditions are employed, the time step is $1.0 \mathrm{fs}$, and the temperature is $298 \mathrm{~K}$.

A set of additional MD simulations employing an enhanced sampling approach (the metadynamics method) were performed to quantify the energetics and associated time scales of molecular processes in the hydrated Na-hectorite interlayers. These accelerated free energy calculations were performed at two hydration levels that correspond to $1 \mathrm{WL}$ and $2 \mathrm{WL}$ hydrates $\left(\mathrm{H}_{2} \mathrm{O} / \mathrm{Na}^{+}=3\right.$ and 10$)$, determined from the $N P T$ MD simulations. The metadynamics calculations are carried out using a model system consisting of 128 formula units ( $8 a \times 8 b \times 2 c$ ) based on the structure of Breu et al. ${ }^{124}$ with $\mathrm{Na}^{+}$as the counter ion and using the Collective Variable Module implemented in NAMD version $2.9^{147,148}$ and the CLAYFF force field parameters. ${ }^{25}$ Two reaction coordinates are defined: (i) the angle, $\theta$, formed by the normal to the clay basal surface and the vector between the $\mathrm{Na}^{+}$ion and the Онго atom of one of its coordinating $\mathrm{H}_{2} \mathrm{O}$ molecules ( $\mathrm{SN}-\mathrm{Na}-\mathrm{O}_{\mathrm{H} 2 \mathrm{O}}$ ) and (ii) the angle, $\varphi$, between the two vectors

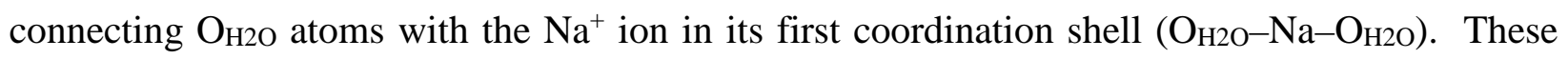
angles are depicted in Figure 2. The free energy profiles are computed as a function of these reaction coordinates from independent simulations performed under NPT conditions at $298 \mathrm{~K}$ 
and 1 atmosphere pressure. The calculations are 15 - 20 ns in length, during which Gaussian hills $2^{\circ}$ in width and $0.08 \mathrm{~kJ} / \mathrm{mol}$ in height were added every $100 \mathrm{fs}$. Distance restraints are imposed to ensure that tagged water molecules remain in the first coordination shell of a chosen $\mathrm{Na}^{+}$ion during the entire course of the simulation. ${ }^{149}$

\subsection{Simulation Analysis}

A number of structural parameters are extracted for each sample from the MD simulations described above. The distributions of $\mathrm{Na}^{+}$, $\mathrm{O}_{\mathrm{H} 2 \mathrm{O}}$, and $\mathrm{H}_{\mathrm{H} 2 \mathrm{O}}$ perpendicular to the plane of the clay layers are analyzed with atomic density profiles (z-density plots), where $z=0$ corresponds to the center of the interlayer plane. The orientation of the interlayer water molecules is evaluated using the angles formed by the vector bisecting the $\mathrm{O}_{\mathrm{H} 2 \mathrm{O}}$ atom and its two $\mathrm{H}_{\mathrm{H} 2 \mathrm{O}}$ atoms $\left(\mathrm{H}_{2} \mathrm{O}\right.$ dipole vector) with the normal to the basal clay surface (SN-O $\left.\mathrm{O}_{22}-\mathrm{H}_{\mathrm{HBi}}\right), \omega$, and the angles formed by the normal to the clay basal surface and the vector between the $\mathrm{Na}^{+}$ion and the $\mathrm{O}_{22} \mathrm{O}$ atoms of its coordinating $\mathrm{H}_{2} \mathrm{O}$ molecules ( $\mathrm{SN}-\mathrm{Na}-\mathrm{O}_{\text {H2O }}$ ), $\theta$. For each of these, the basal clay surface closest to either $\mathrm{Na}^{+}$or $\mathrm{O}_{\mathrm{H} 2 \mathrm{O}}$ (i. e. the central atom of the angle) is used, and Figure 2 shows the definitions of these angles. The cutoff for each vector is the base of the first peak in the radial distribution function (RDF) between each pair of relevant atoms. The local coordination environments of $\mathrm{Na}^{+}$by the basal oxygen atoms of the clay layers (OMIN) and water molecules $\left(\mathrm{O}_{\mathrm{H} 2 \mathrm{O}}\right)$ are characterized by RDFs and running coordination numbers (RCNs). Surface distributions of $\mathrm{Na}^{+}$ions and $\mathrm{O}_{\mathrm{H} 2 \mathrm{O}}$ atoms are evaluated from atomic density maps that plot the locations of atoms in the $x y$ plane parallel to the plane of the basal $\mathrm{O}$ atoms of the clay layer at each saved point in the trajectory (200 points total). All $\mathrm{Na}^{+}$ions are included in the plots, whereas only the $\mathrm{O}_{\mathrm{H} 2 \mathrm{O}}$ and $\mathrm{H}_{\mathrm{H} 2 \mathrm{O}}$ atoms in the first RDF peak of the $\mathrm{O}_{\mathrm{MIN}}-\mathrm{O}_{\mathrm{H} 2 \mathrm{O}}$ and $\mathrm{O}_{\mathrm{MIN}}-\mathrm{H}_{\mathrm{H} 2 \mathrm{O}}$, 
respectively, are included for these species. The hydrogen bonding networks are evaluated by using the geometric definition of H-bonding criteria ${ }^{150}$ previously employed for hydrated layered systems..$^{27,36,78,79}$ In this definition, the intermolecular $\mathrm{O} \cdots \mathrm{O}$ distances of an $\mathrm{H}$-bonded pair of species are less than $3.5 \AA$, which is comparable to $\mathrm{O} \cdots \mathrm{O}$ distances in hydrated Nafluorhectorite, ${ }^{91}$ and the $\mathrm{H}-\mathrm{O} \cdots \mathrm{O}$ angles are less than $30^{\circ} .{ }^{150}$ Water molecules that meet both of these criteria are considered to be participating in a HB.

The hydration energy was calculated using the relationship:

$$
\Delta U_{H}(N)=\frac{\langle U(N)\rangle-\langle U(0)\rangle}{N}
$$

where $\langle U(N)\rangle$ is the average potential energy of an equilibrium system containing $N$ water molecules and $\langle U(0)\rangle$ is the average potential energy of the equilibrated anhydrous system. The hydration energies of smectite clays and layered double hydroxides (LDHs) have been previously evaluated with this approach. ${ }^{18,19,21,31,36,78,79} P \Delta V$ is negligible at ambient pressures, ${ }^{77}$ and $\Delta U_{\mathrm{H}}(N)$ is thus a close approximation of the enthalpy of hydration.

The diffusion coefficients of $\mathrm{Na}^{+}$ions and $\mathrm{H}_{2} \mathrm{O}$ molecules are calculated for all simulations from the mean-square displacements of these species from the relationship:

$$
\left\langle x^{2}\right\rangle=4 D t
$$

where $\left\langle x^{2}\right\rangle$ is the mean square displacement, the coefficient 4 represents 2-dimensional diffusion, $D$ is the diffusion coefficient, and $t$ is the time over which the displacement is averaged. The 2dimensional diffusion coefficient is appropriate for the interlayer galleries because there is minimal diffusion in the direction perpendicular to the layers. ${ }^{31,65,112,113}$ 


\section{Results and Discussion}

\subsection{Na-Hectorite Structure}

The average $a$ - and $b$ - unit cell parameters calculated for the Na-hectorite molecular models are $a=5.2072 \AA$ and $b=8.9482 \AA$, within $3 \%$ of experimental values, ${ }^{91,124}$ and the $c$ axis increases with increasing water content. For all systems studied, the average unit cell angles are $\alpha=86.62^{\circ}, \beta=96.66^{\circ}$, and $\gamma=90.00^{\circ}$, which are within $4 \%$ of experimental values. ${ }^{91,124}$ The greatest deviations in cell parameters occur for the least and most hydrated samples, particularly for the cell angles. Figure 1 shows cross sections of the structures with $\mathrm{H}_{2} \mathrm{O} / \mathrm{Na}^{+}=0,0.6,3,5.5$, and 10.

\subsection{Identifying One-, One-and-One-Half-, and Two-Layer Hydrates}

The samples with $\mathrm{H}_{2} \mathrm{O} / \mathrm{Na}^{+}$ratios of $0,0.6,3,5.5$, and 10 illustrated in Figure 1 represent the most important hydration levels. The 0 and $0.6 \mathrm{H}_{2} \mathrm{O} / \mathrm{Na}^{+}$samples are the computationally dry and equivalent moisture content to the "dry" samples from our previous spectroscopic study, respectively. TGA experiments for Na-hectorite samples held over $\mathrm{P}_{2} \mathrm{O}_{5}$ yield $\mathrm{H}_{2} \mathrm{O} / \mathrm{Na}^{+}=0.6 .{ }^{46}$ The 3, 5.5, and $10 \mathrm{H}_{2} \mathrm{O} / \mathrm{Na}^{+}$samples correspond to the one- (1 WL), one-and-one-half- (1.5 WL), and two-water-layer (2 WL) hydrates, respectively, as shown by the calculated hydration energies (Figure 3), the atomic density profiles (z-density plots; Figure 4), and computed interlayer spacing (Figure 5).

Previous investigations of interlayer hydration use several tools to identify one- and twolayer hydrates, including relative humidity $(\mathrm{RH}), m_{\mathrm{H} 2 \mathrm{O}} / m_{\text {MATERIAL }} d$-spacing, atomic density plots, hydration energy, and orientation of $\mathrm{H}_{2} \mathrm{O}$ molecules with respect to the clay

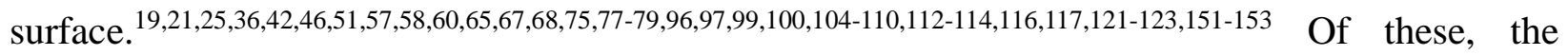


computational tools that provide the most informative results are the hydration energy curves as a function of the water content and the atomic density profiles. Minima in the hydration energy correspond to thermodynamically stable states. Although these energies neglect entropic contributions, these are expected to be small at ambient temperatures. ${ }^{76,77}$ Atomic density profiles complement the analysis based on hydration energy. ${ }^{18,19,51,75,77,96,104,105,110,112,113,116,122}$

The computed hydration energies for our Na-hectorite model (Figure 3) show a large range of values. The $0 \mathrm{H}_{2} \mathrm{O} / \mathrm{Na}^{+}$sample is higher in energy than the bulk SPC value (-40.10 $\mathrm{kJ} / \mathrm{mol}){ }^{135}$ which indicates a hydrophobic environment. ${ }^{32}$ At all higher hydration levels, however, the hydration energy is more negative than for bulk SPC water, consistent with the known swelling behavior of Na-hectorite. ${ }^{46}$ Minima are located at 3, 5.5, and $8.5-10 \mathrm{H}_{2} \mathrm{O} / \mathrm{Na}^{+}$. The minimum at $3 \mathrm{H}_{2} \mathrm{O} / \mathrm{Na}^{+}$corresponds to the $1 \mathrm{WL}$ structure, the minimum at $5.5 \mathrm{H}_{2} \mathrm{O} / \mathrm{Na}^{+}$to the $1.5 \mathrm{WL}$ structure, and the minimum at $8.5-10 \mathrm{H}_{2} \mathrm{O} / \mathrm{Na}^{+}$to the $2 \mathrm{WL}$ structure. Recent TGA experiments and structural refinement analyses of Na-fluorhectorite hydration indicated the $\mathrm{H}_{2} \mathrm{O} / \mathrm{Na}^{+}$compositions of 3.2 and $5.6\left(\mathrm{H}_{2} \mathrm{O} / 8 \mathrm{Si}=4.5\right.$ and 7.8$)$ for the $1 \mathrm{WL}$ and $2 \mathrm{WL}$ hydrates, respectively. ${ }^{91}$ While the first value is in good agreement with our $1 \mathrm{WL}$ composition, the second one would appear to correspond to $1.5 \mathrm{WL}$ in our nomenclature. In our simulations, however, the hectorite layer charge and thus the number of interlayer cations required for charge balance is $30 \%$ lower than in the samples used experimentally by Kalo, et al.: 0.5 vs 0.7 Na per formula unit, respectively. ${ }^{91}$ Thus, our systems require more $\mathrm{H}_{2} \mathrm{O}$ molecules per interlayer cation to fill the interlayer space. The broad minimum in the $2 \mathrm{WL}$ region of the hydration curve is expected because samples with basal spacing similar to this structure are stable over a broad range of RHs. $39,40,57,58,60,68,77,105,110,122,151-153$ 
The z-density plots (Figure 4) are especially important for characterizing the $2 \mathrm{WL}$ structure because of the broad hydration energy minimum in this region. We choose the 10 $\mathrm{H}_{2} \mathrm{O} / \mathrm{Na}^{+}$sample shown in Figure 4 to represent this hydration state because there is a single $\mathrm{Na}^{+}$ layer located in the center of the interlayer, two well-defined $\mathrm{O}_{\mathrm{H} 2 \mathrm{O}}$ layers on either side of the $\mathrm{Na}^{+}$layer, and two well-defined $\mathrm{H}_{\mathrm{H} 2 \mathrm{O}}$ maxima for each $\mathrm{O}_{\mathrm{H} 2 \mathrm{O}}$ layer in our RDFs. However, the structure does not change greatly in this compositional range. The snapshot of the $2 \mathrm{WL}$ hydrate in Figure 1 along with the z-density plot in Figure 4 are comparable to the structural features in the $2 \mathrm{WL}$ for Na-fluorhectorite in recent experiments ${ }^{91}$ and Na-montmorillonite in recent simulations. ${ }^{77,110}$ In all these studies, $\mathrm{Na}^{+}$ions are located in the center of the interlayer, and the organization of water layers is characterized by the presence of a single $\mathrm{O}_{\mathrm{H} 20}$ peak for each water layer. ${ }^{77,91,110}$ One additional possibility as to why our water contents for the 2 WL differ from those of Kalo et al. is that experimentally there may be vacancies in the water layers, ${ }^{91}$ whereas our model does not have vacancies (Figure 1).

The computed relationship between interlayer (basal) spacing and hydration level for our Na-hectorite (Figure 5) shows multiple steps and is generally similar to previous results for other smectite phases. ${ }^{18,19,21,25,45,68,75,81,99,101,105,106,108-110,112,113,116,121,123,152}$ The computationally dry and experimentally dry samples have basal spacings of 9.4 and $9.7 \AA$, in good agreement with the experimental value of $9.7 \pm 0.2 \AA$ for San Bernandino hectorite with $0.6 \mathrm{H}_{2} \mathrm{O} / \mathrm{Na}^{+}{ }^{46}$ Thus, using all $\mathrm{OH}^{-}$groups in our simulation instead of partial substitution by $\mathrm{F}^{-}$does not have a significant effect on the agreement between the observed and computed basal spacing values. At higher hydration levels, plateau regions at $2-5 \mathrm{H}_{2} \mathrm{O} / \mathrm{Na}^{+}$and $7.5-10 \mathrm{H}_{2} \mathrm{O} / \mathrm{Na}^{+}$correspond to the hydration energy minima for the $1 \mathrm{WL}$ and $2 \mathrm{WL}$ hydrates, respectively. The computed basal 
spacings of 11.8 and $15.2 \AA$ are remarkably close to experimental values of $11.8-12.6$ and 15.0 $-15.1 \AA$ for those hydration states. ${ }^{46,91}$

The 1.5 WL hydrate with an energy minimum at $\mathrm{H}_{2} \mathrm{O} / \mathrm{Na}^{+}=5.5$ does not correspond to a plateau in the basal spacing/hydration relationship, and the existence of a stable structure at this hydration level has been controversial. An experimental study of Li-fluorhectorite ${ }^{45}$ and a computational study of Li-montmorillonite identified 1.5 WL hydrates for these minerals, ${ }^{110}$ whereas experimental XRD data suggest that a $1.5 \mathrm{WL}$ hydrate does not occur for Nafluorhectorite. ${ }^{45}$ This study, however, examined Na-fluorhectorite hydration at greater hydration intervals than for Li-fluorhectorite, and development of a $1.5 \mathrm{WL}$ sample may have been missed. Moreover, oscillation between $1 \mathrm{WL}$ and 2 WL hydrates occurred in early Monte Carlo simulations of montmorillonite hydration for $\mathrm{H}_{2} \mathrm{O} / \mathrm{Li}^{+}=6.5$ and $\mathrm{H}_{2} \mathrm{O} / \mathrm{Na}^{+}=8 .{ }^{18}$ As discussed above, the stability of an interlayer gallery structure is controlled by the tradeoffs among many interactions, and deeper understanding of the physicochemical controls of the stability of $1.5 \mathrm{WL}$ smectite hydrates is needed. In our simulations of the $5.5 \mathrm{H}_{2} \mathrm{O} / \mathrm{Na}^{+}$sample, neither the $\mathrm{Na}^{+}$ions nor the $\mathrm{H}_{2} \mathrm{O}$ molecules $\left(\mathrm{O}_{\mathrm{H}} \mathrm{O}\right.$ and $\mathrm{H}_{\mathrm{H} 2 \mathrm{O}}$ ) occur in well-defined planes in the interlayers (Figures $1 \mathrm{~d}$ and 4), but as described in detail below, this structure is characterized by a well-defined 5coordinate nearest neighbor $\mathrm{Na}^{+}$environment with $4 \mathrm{O}_{\mathrm{H} 2 \mathrm{O}}$ and $1 \mathrm{O}_{\mathrm{MIN}}$ and is near a maximum in the number of $\mathrm{H}$-bonds/water molecule. Thus, the tendency towards stability of the $1.5 \mathrm{WL}$ structure appears to be driven by cation coordination and the development of a well defined HB network.

\section{3. $\mathrm{Na}^{+}-\mathrm{H}_{2} \mathrm{O}$ Interlayer Structure}


RDFs and RCNs for $\mathrm{Na}-\mathrm{O}_{\mathrm{MIN}}$ and $\mathrm{Na}-\mathrm{O}_{\mathrm{H} 2 \mathrm{O}}$ (Figure 6) show large changes in the $\mathrm{Na}^{+}$ coordination environment that parallel the changes in hydration energy and basal spacing. Overall, $\mathrm{Na}^{+}$coordination by $\mathrm{O}_{\mathrm{MIN}}$ is greater than $\mathrm{O}_{\mathrm{H} 2 \mathrm{O}}$ up to about $2.5 \mathrm{H}_{2} \mathrm{O} / \mathrm{Na}^{+}$and is less than $\mathrm{O}_{\mathrm{H} 2 \mathrm{O}}$ at higher values. In the $0 \mathrm{H}_{2} \mathrm{O} / \mathrm{Na}^{+}$sample, the mean $\mathrm{Na}-\mathrm{O}_{\text {MIN }}$ distance is $3.23 \AA$, which is comparable to the experimental value of $3.290-3.319 \AA .{ }^{124} \mathrm{Na}^{+}$is coordinated by $5.5 \mathrm{O}_{\mathrm{MIN}}$, and the $\mathrm{Na}^{+}$ions are located on one side of the interlayer or the other (Figure 1a and Figure 4). For the $0.6 \mathrm{H}_{2} \mathrm{O} / \mathrm{Na}^{+}$sample, $\mathrm{Na}^{+}$is coordinated by $7.4 \mathrm{O}_{\text {MIN }}$ and $0.5 \mathrm{O}_{\mathrm{H} 2 \mathrm{O}}$, the mean $\mathrm{Na}-\mathrm{O}_{\mathrm{MIN}}$ distance is $3.48 \AA$, and the mean $\mathrm{Na}-\mathrm{O}_{\mathrm{H} 2 \mathrm{O}}$ distance is $2.68 \AA$. MD simulation of aqueous $\mathrm{NaCl}$ solution yielded a mean $\mathrm{Na}-\mathrm{O}_{\mathrm{H} 2 \mathrm{O}}$ distance of $2.33 \AA \AA^{154}$ The slightly larger value for Na-hectorite probably reflects the structural restrictions imposed by the basal $\mathrm{O}$ atoms on either side of the interlayer. As for the $0 \mathrm{O}_{\mathrm{H} 2 \mathrm{O}} / \mathrm{Na}^{+}$composition, the $\mathrm{Na}^{+}$ions are coordinated by $\mathrm{O}_{\text {MIN }}$ on both sides of the interlayer.

For the $1 \mathrm{WL}$ structure, $\mathrm{Na}^{+}$is coordinated on average by $1.8 \mathrm{O}_{\text {MIN }}$ and $3.5 \mathrm{O}_{\text {H2O, and the }}$ mean $\mathrm{Na}-\mathrm{O}_{\mathrm{MIN}}$ and $\mathrm{Na}-\mathrm{O}_{\mathrm{H} 2 \mathrm{O}}$ distances are 3.03 and $3.38 \AA$, respectively. The partial coordination of $\mathrm{Na}^{+}$by both $\mathrm{O}_{\mathrm{MIN}}$ and $\mathrm{O}_{\mathrm{H} 2 \mathrm{O}}$ is expected for Na-hectorite. ${ }^{91}$ In the $1.5 \mathrm{WL}$ sample,

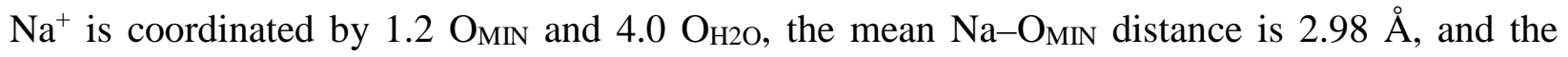
mean $\mathrm{Na}-\mathrm{O}_{\mathrm{H} 2 \mathrm{O}}$ distance is $3.18 \AA$. For the $2 \mathrm{WL}$ structure, $\mathrm{Na}^{+}$is in outer-sphere coordination by on average $6.0 \mathrm{O}_{\mathrm{H} 2 \mathrm{O}}$ and $0 \mathrm{O}_{\mathrm{MIN}}$ with a mean $\mathrm{Na}-\mathrm{O}_{\mathrm{H} 2 \mathrm{O}}$ distance of $3.18 \AA$ (Figure 6). The mean Na-OMIN distance of $5.28 \AA$ at the minimum following the first RDF peak reflects the outersphere coordination. The $\mathrm{Na}-\mathrm{O}_{\mathrm{H} 2 \mathrm{O}}$ coordination compares well to $6.0 \mathrm{CN}$ for $\mathrm{Na}-\mathrm{O}_{\mathrm{H} 2 \mathrm{O}}$ in recent experiments of Na-fluorhectorite hydration, ${ }^{91} 5.8$ in recent simulations of aqueous $\mathrm{NaCl}$ solutions, ${ }^{154-156}$ and to 6.0 in simulations of the $2 \mathrm{WL}$ hydrate in Na-montmorillonite. ${ }^{77} \mathrm{Na}-\mathrm{O}_{\mathrm{H} 2 \mathrm{O}}$ 
distances of 3.15 - $3.2 \AA$ occur for the 2 WL hydrate of Na-montmorillonite. ${ }^{77,118}$ Outer-sphere coordination of $\mathrm{Na}^{+}$ions is expected for clays with octahedral substitution. ${ }^{109,118}$

H-bonding is important in stabilizing hydrated interlayer galleries, and for smectite interlayers, the $\mathrm{HB}$ structure can be characterized by the total number of $\mathrm{HBs} / \mathrm{H}_{2} \mathrm{O}$, which includes the number of $\mathrm{H}$-bonds donated to the $\mathrm{O}_{\mathrm{MIN}}$ as well as the number of $\mathrm{H}$-bonds donated to and accepted from other $\mathrm{H}_{2} \mathrm{O}$ molecules, and the fraction of $\mathrm{H}_{2} \mathrm{O}$ molecules with different numbers of HBs (Figure 7). By the definition of an HB that we use, there are no HBs donated to the $\mathrm{O}_{\text {н2о }}$ by the $\mathrm{OH}^{-}$groups of the TOT octahedral layer, in accord with MD simulation of montmorillonite hydration. ${ }^{51}$ Overall, as hydration level increases, the number of $\mathrm{HBs} / \mathrm{H}_{2} \mathrm{O}$ increases from approximately 1.2 in the experimentally dry sample to approximately 2.9 for the 2 WL hydrate, slightly less than the bulk value of 3.5 for bulk SPC water, ${ }^{27}$ and the majority of $\mathrm{H}_{2} \mathrm{O}$ molecules have 2, 3, or $4 \mathrm{HBs}$ at the highest hydration levels. For the experimentally dry composition of $0.6 \mathrm{H}_{2} \mathrm{O} / \mathrm{Na}^{+}, \mathrm{H}_{2} \mathrm{O}$ molecules donate $1.2 \mathrm{HBs}$ to $\mathrm{O}_{\text {MIN }}$ and due to the large separation between water molecules donate and accept 0.0 to/from one another. As the hydration level increases, the number of HBs donated to OMIN decreases, and the number donated/accepted to/from other $\mathrm{H}_{2} \mathrm{O}$ molecules increases. For the $1 \mathrm{WL}$ structure, $\mathrm{HB}$ donation is still principally to $\mathrm{O}_{\text {MIN. }}$. The total number of $\mathrm{HBs} / \mathrm{H}_{2} \mathrm{O}$ is 1.7 , with each water molecule donating on average 1.5 HBs to the $\mathrm{O}_{\mathrm{MIN}}$, accepting 0.1 from other water molecules, and donating 0.1 to other water molecules. Because the $\mathrm{O}_{\mathrm{H} 2 \mathrm{O}}$ do not accept HBs from other species, the latter two values must always be identical. At hydration levels greater than $3 \mathrm{H}_{2} \mathrm{O} / \mathrm{Na}^{+}$, the number of $\mathrm{HBs}$ among $\mathrm{H}_{2} \mathrm{O}$ molecules increases, and for the $1.5 \mathrm{WL}$ structure at $5.5 \mathrm{H}_{2} \mathrm{O} / \mathrm{Na}^{+}$, the number of $\mathrm{HBs}$ donated to $\mathrm{O}_{\mathrm{MIN}}(0.9)$ and donated/accepted to/from $\mathrm{O}_{\mathrm{H} 2 \mathrm{O}}(0.9$ each) are approximately equal. The total number of $\mathrm{HBs} / \mathrm{H}_{2} \mathrm{O}$ is 2.6, very close to the value of 2.9 for the $2 \mathrm{WL}$ structure at $10 \mathrm{H}_{2} \mathrm{O} / \mathrm{Na}^{+}$, 
indicating that this relatively well integrated HB network plays an important role in stabilizing this structure. Similar HB networks comprised of $\mathrm{HBs}$ donated to $\mathrm{O}_{\mathrm{MIN}}$ atoms and donated/accepted to/from other $\mathrm{H}_{2} \mathrm{O}$ molecules also occurs for Na-fluorhectorite and Na-saponite at this range of hydration states. ${ }^{91,121}$ At hydration levels greater than $5.5 \mathrm{H}_{2} \mathrm{O} / \mathrm{Na}^{+}$, the number of $\mathrm{HBs} / \mathrm{H}_{2} \mathrm{O}$ donated/accepted to/from other $\mathrm{H}_{2} \mathrm{O}$ molecules exceeds those donated to $\mathrm{O}_{\text {MIN. }}$. In the relatively well-developed $\mathrm{HB}$ network of the 2 WL hydrate, each $\mathrm{H}_{2} \mathrm{O}$ donates and accepts 1.1 $\mathrm{HB}$ to/from other $\mathrm{H}_{2} \mathrm{O}$ molecules and donates about 0.7 to the $\mathrm{O}_{\mathrm{MIN}}$ atoms.

The fraction of $\mathrm{H}_{2} \mathrm{O}$ molecules having a given total number of $\mathrm{HBs}$ also varies systematically and is related to the hydration energy. In the $0.6 \mathrm{H}_{2} \mathrm{O} / \mathrm{Na}^{+}$sample, the majority of $\mathrm{H}_{2} \mathrm{O}$ molecules have 1 or $2 \mathrm{HBs}$, with a smaller fraction having 0 HBs. Similarly, for the $1 \mathrm{WL}$ sample, most $\mathrm{H}_{2} \mathrm{O}$ molecules have 1 or $2 \mathrm{HBs}$, with smaller fractions having 0 or $3 \mathrm{HBs}$. At 5.5 $\mathrm{H}_{2} \mathrm{O} / \mathrm{Na}^{+}$(the $1.5 \mathrm{WL}$ sample), the interlayer $\mathrm{HB}$ network is reasonably well integrated, the majority of $\mathrm{H}_{2} \mathrm{O}$ molecules have 2, 3, or $4 \mathrm{HBs}$, and there is less change with increasing water content than at lower hydration levels. These results point to the development of an interlayer HB network as an important contributor to stabilizing the $1.5 \mathrm{WL}$ hydrate.

The structure of smectite interlayer galleries is also characterized by the orientation of $\mathrm{Na}^{+}$and $\mathrm{H}_{2} \mathrm{O}$ molecules with respect to the basal clay surface (see Figure 2). The coordination of $\mathrm{Na}^{+}$by $\mathrm{H}_{2} \mathrm{O}$ is described by the angle between the clay surface normal (SN) and the nearest neighbor $\mathrm{Na}-\mathrm{O}_{\mathrm{H} 2 \mathrm{O}}$ vector. The orientation of $\mathrm{H}_{2} \mathrm{O}$ molecules with respect to the clay surface is described by the angle between the SN and the vector bisecting the $\mathrm{H}-\mathrm{O}-\mathrm{H}$ angle of $\mathrm{H}_{2} \mathrm{O}$ molecules (their molecular dipole vector). This latter quantity can be compared directly to the angles determined by ${ }^{2} \mathrm{H}$ NMR results for Na-hectorite. ${ }^{46}$ The mean $\mathrm{SN}-\mathrm{Na}-\mathrm{O}_{\mathrm{H} 2 \mathrm{O}}$ values reported here reflect averaging over all nearest neighbor $\mathrm{Na}^{+}$coordination shells across the last 
100 ps of the final NVT MD trajectory. The mean computed $\mathrm{SN}-\mathrm{O}_{\mathrm{H} 2 \mathrm{O}}-\mathrm{H}_{\mathrm{HBi}}$ angle is the average for all $\mathrm{H}_{2} \mathrm{O}$ molecules over the last 100 ps of the final $N V T$ trajectory. The experimentally determined $\mathrm{SN}-\mathrm{O}_{\mathrm{H} 2 \mathrm{O}}-\mathrm{H}_{\mathrm{HBi}}$ angle reflects time averaging over the $\mathrm{T}_{2}{ }^{*}$ time of the NMR free induction decay, which is in the ms range. Table 1 presents the computed averages of these angles for each composition modeled, and Figure 8 shows the computed distributions of these angles for $0,0.6,3,5.5$, and $10 \mathrm{H}_{2} \mathrm{O} / \mathrm{Na}^{+}$.

As hydration level increases, the average $\mathrm{SN}-\mathrm{O}_{\mathrm{H} 2 \mathrm{O}}-\mathrm{H}_{\mathrm{HBi}}$ angle decreases (Table 1), reflecting the change in orientation of the water molecules as HB donation to the $\mathrm{O}_{\mathrm{MIN}}$ decreases and $\mathrm{HB}$ donation among the $\mathrm{H}_{2} \mathrm{O}$ molecules increases. For $\mathrm{H}_{2} \mathrm{O} / \mathrm{Na}^{+}$values from 7.5 to 12 , which include the range of hydration states with energies comparable to that for the best-defined $2 \mathrm{WL}$ structure, this angle varies from $51^{\circ}$ to $53^{\circ}$. This value is in excellent agreement with the experimental results for a 2 WL sample of ${ }^{2} \mathrm{H}_{2} \mathrm{O}$-exchanged San Bernandino hectorite. ${ }^{46}$ Simulation of the ${ }^{2} \mathrm{H}$ NMR resonance of this sample yields a value of either $51^{\circ}$ or $59^{\circ}$, since the line widths and residual splitting are symmetric with respect to the octahedral angle of $54.7^{\circ}$. The agreement between the computed value and the observed value of $51^{\circ}$ to $53^{\circ}$ supports the smaller of these two angles. This orientation results from the $\mathrm{H}_{2} \mathrm{O}$ molecules typically having one $-\mathrm{OH}$ group donating a $\mathrm{HB}$ to an $\mathrm{O}_{\mathrm{MIN}}$ (the $\mathrm{H}_{\mathrm{H} 2 \mathrm{O}}$ peak closest to the surface in Figure 4) and the other $\mathrm{OH}$ group donating a $\mathrm{HB}$ to another water molecule (the $\mathrm{H}_{\mathrm{H} 2 \mathrm{O}}$ peak at nearly the same position as the Онго peak in Figure 4), which occurs for hydrated montmorillonite as well. ${ }^{18}$ This orientation is observable in the snapshot in Figure 1e. At the lowest hydration level of 0.6 $\mathrm{H}_{2} \mathrm{O} / \mathrm{Na}^{+}$, the dipole is oriented $71^{\circ}$ toward the surface, reflecting the close association of the $\mathrm{H}_{2} \mathrm{O}$ molecules to the surface. For the $1 \mathrm{WL}$ hydrate, the $\mathrm{SN}-\mathrm{O}_{\mathrm{H} 2 \mathrm{O}}-\mathrm{H}_{\mathrm{HBi}}$ angle is $78^{\circ}$, reflecting the large number of $\mathrm{HBs}$ donated to $\mathrm{O}_{\mathrm{MIN}}$ and the development of a well-defined $\mathrm{H}_{2} \mathrm{O}+\mathrm{Na}^{+}$ 
layer in the center of the interlayer. Similar results occur in Monte Carlo simulations of hydrated montmorillonite ${ }^{18}$ and NMR experiments with Na-fluorhectorite. ${ }^{44}$ For the 1.5 WL hydrate sample, the $\mathrm{SN}-\mathrm{O}_{\mathrm{H} 2 \mathrm{O}}-\mathrm{H}_{\mathrm{HBi}}$ angle is $60^{\circ}$, reflecting the increased $\mathrm{HB}$ donation among the water molecules. The changes in the distribution of the $\mathrm{SN}-\mathrm{O}_{\mathrm{H} 2 \mathrm{O}}-\mathrm{H}_{\mathrm{HBi}}$ angles with increasing hydration indicate the structural reorientation of $\mathrm{H}_{2} \mathrm{O}$ molecules in the interlayer as more molecules are added to the interlayer galleries. For $\mathrm{H}_{2} \mathrm{O} / \mathrm{Na}^{+}=0.6$ and 3.0, the maxima are at $90^{\circ}$, with tails to lower angles. At $\mathrm{H}_{2} \mathrm{O} / \mathrm{Na}^{+}=5.5$ and 10 , there are well-defined maxima at lower values and many fewer large values.

The changes in the $\mathrm{SN}-\mathrm{Na}-\mathrm{O}_{\mathrm{H} 2 \mathrm{O}}$ angles also reflect the changes in the interlayer structure. For the experimentally dry sample at $\mathrm{H}_{2} \mathrm{O} / \mathrm{Na}^{+}=0.6$, the $\mathrm{SN}-\mathrm{Na}-\mathrm{O}_{\mathrm{H} 2 \mathrm{O}}$ angle is $54^{\circ}$, due to the $\mathrm{Na}^{+}$ions and the $\mathrm{H}_{2} \mathrm{O}$ molecules being at approximately the same level in the

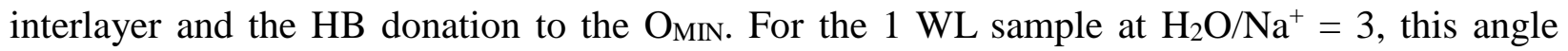
increases to $83^{\circ}$, reflecting the presence of the $\mathrm{Na}^{+}$ions and the $\mathrm{H}_{2} \mathrm{O}$ molecules in the center of the interlayer and the large number of HBs donated to the $\mathrm{O}_{\text {MIN. }}$ For the $1.5 \mathrm{WL}$ sample at $\mathrm{H}_{2} \mathrm{O} / \mathrm{Na}^{+}=5.5$, this angle decreases to $71^{\circ}$, reflecting increased $\mathrm{HB}$ donation among the water molecules. For the $2 \mathrm{WL}$ sample at $\mathrm{H}_{2} \mathrm{O} / \mathrm{Na}^{+}=10$, the value is $55^{\circ}$, essentially equal to the value of $54.7^{\circ}$ for ideal octahedral coordination and reflecting $\mathrm{Na}^{+}$coordination by only water molecules. At higher hydrations of 11 and $12 \mathrm{H}_{2} \mathrm{O} / \mathrm{Na}^{+}$, this angle increases, but we have not investigated higher hydration states leading to osmotic swelling that would shed light on these changes.

\section{4. $\mathrm{Na}^{+}$Ions and $\mathrm{H}_{2} \mathrm{O}$ Positions Parallel to the Clay Surface}


For the most dehydrated samples, the $\mathrm{Na}^{+}$ions lie at the center of $\mathrm{Si}-\mathrm{O}$ hexagonal rings on the sheet to which they are closest and, for the $\mathrm{H}_{2} \mathrm{O} / \mathrm{Na}^{+}=0.6$ sample, are generally coordinated by one or two basal OMIN atoms of the opposite sheet (Figure 9). $\mathrm{Na}^{+}$ions remain relatively immobile in these positions and do not undergo diffusion out of their hexagonal ring. In the computationally dry sample, $\left(\mathrm{H}_{2} \mathrm{O} / \mathrm{Na}^{+}=0\right) \mathrm{Na}^{+}$ions hop from one side of the interlayer to the other, resulting in the pairs of $\mathrm{Na}^{+}$points in Figure 9 (such as for $x=0 \AA$ and $y=7.5 \AA$ ). This behavior does not occur in the experimentally dry sample $\left(\mathrm{H}_{2} \mathrm{O} / \mathrm{Na}^{+}=0.6\right)$. As hydration increases, the $\mathrm{Na}^{+}$ions begin to diffuse (Table 2), and their location at specific sites becomes less well-defined. In the $1 \mathrm{WL}$ hydrate, $\mathrm{Na}^{+}$ions move from their positions at the center of $\mathrm{Si}-\mathrm{O}$ hexagonal rings but remain primarily within the vicinity of these sites. Previous experiments for the $1 \mathrm{WL}$ hydrate of Na-fluorhectrotie ${ }^{91}$ and MD simulation of the $1 \mathrm{WL}$ hydrate of Namontomorillonite show a similar behavior for interlayer $\mathrm{Na}^{+}$and highlight the importance of considering $\mathrm{O}_{\mathrm{MIN}}$ atoms on both sides of the interlayer. ${ }^{101}$ For the 1.5 and 2 WL hydrates, diffusion of the $\mathrm{Na}^{+}$ions is evident by the increased distribution of the atom positions (Figure 9), and location at specific sites within the Si-O hexagonal rings is poorly defined.

The $\mathrm{H}_{2} \mathrm{O}$ molecules in the experimentally dry $\left(\mathrm{H}_{2} \mathrm{O} / \mathrm{Na}^{+}=0.6\right)$ sample are relatively stationary in the center of the $\mathrm{Si}-\mathrm{O}$ hexagonal rings (Figure $9 \mathrm{~b}$ and c), similar to $\mathrm{H}_{2} \mathrm{O}$ molecules in the interlayers of the $10 \AA$ phase. ${ }^{26}$ For this composition, Figure $9 \mathrm{~b}$ shows $\mathrm{O}_{\mathrm{H} 2 \mathrm{O}}$ and $\mathrm{H}_{\mathrm{H} 2 \mathrm{O}}$ atoms within $3.28 \AA$ and $2.78 \AA$ of the basal O atoms, respectively. The preferential location of $\mathrm{H}_{2} \mathrm{O}$ molecules on one side of the interlayer (Figure 4) as well as the small basal spacing (Figure 5) allow $\mathrm{H}_{2} \mathrm{O}$ molecules to donate $\mathrm{HBs}$ to $\mathrm{O}_{\text {MIN }}$ atoms on either side of the interlayer, and the HBs from $\mathrm{H}_{2} \mathrm{O}$ are donated entirely to the basal $\mathrm{O}$ atoms at this hydration level (Figure 7). The majority of $\mathrm{HBs}$ are between $\mathrm{H}_{2} \mathrm{O}$ molecules and $\mathrm{O}_{\mathrm{MIN}}$ atoms on the same side of the interlayer. 
In the $1 \mathrm{WL}$ sample $\left(\mathrm{H}_{2} \mathrm{O} / \mathrm{Na}^{+}=3\right)$, the position of $\mathrm{O}_{\mathrm{H} 2 \mathrm{O}}$ atoms in the center of the interlayer plane (Figure 4) enables them to donate $\mathrm{HBs}$ to a nearly equal number of $\mathrm{O}_{\mathrm{MIN}}$ atoms on either side of the interlayer. Figure 9 shows $\mathrm{O}_{\mathrm{H} 2 \mathrm{O}}$ and $\mathrm{H}_{\mathrm{H} 2 \mathrm{O}}$ atoms within $3.88 \AA$ and $2.38 \AA$ of basal O atoms, respectively. The $1.5 \mathrm{WL}$ hydrate shows a poorly organized arrangement of $\mathrm{H}_{2} \mathrm{O}$ molecules (Figure 4) as shown by the disordered atomic position map (Figure 9b and c) that plots $\mathrm{O}_{\mathrm{H} 2 \mathrm{O}}$ and $\mathrm{H}_{\mathrm{H} 2 \mathrm{O}}$ atoms within $2.98 \AA$ and $2.28 \AA$ of basal $\mathrm{O}$ atoms, respectively. For the $2 \mathrm{WL}$ layer hydrate, the orientation of $\mathrm{H}_{2} \mathrm{O}$ molecules enables a water molecule to donate $\mathrm{HBs}$ to the $\mathrm{O}_{\text {MIN }}$ atoms on one side of the interlayer and to other $\mathrm{H}_{2} \mathrm{O}$ molecules (Figure 4 and Figure 7). For this sample, Figure 9 shows $\mathrm{O}_{\mathrm{H} 2 \mathrm{O}}$ and $\mathrm{H}_{\mathrm{H} 2 \mathrm{O}}$ atoms within $3.03 \AA$ and $2.33 \AA$ of basal $\mathrm{O}$ atoms on the clay surface such that the positions of the $\mathrm{H}_{\mathrm{H} 2 \mathrm{O}}$ atoms reflect the $\mathrm{HB}$ network (Figure 9). There are strong correlations between the $\mathrm{H}_{\mathrm{H} 2 \mathrm{O}}$ and $\mathrm{O}_{\mathrm{MIN}}$ atomic positions in recent $\mathrm{MD}$ simulation of 2 WL hydrates for several layered materials, due to the well-developed HB networks. ${ }^{27,51,67}$

\subsection{Dynamics of $\mathrm{Na}^{+}$Ions and $\mathrm{H}_{2} \mathrm{O}$ Molecules in Interlayer Galleries}

Two-dimensional diffusion coefficients for $\mathrm{Na}^{+}$ions and $\mathrm{H}_{2} \mathrm{O}$ molecules calculated for the 1, 1.5, and 2 WL hydrates increase with increasing hydration, as expected, and the values for $\mathrm{H}_{2} \mathrm{O}$ are systematically larger than for $\mathrm{Na}^{+}$(Table 2). Similar trends have been observed for other swelling clays both experimentally ${ }^{57,60,64,65}$ and computationally, ${ }^{67}$ and our values are generally in good agreement with the published values. Two-dimensional diffusion is appropriate for clay interlayers, because diffusion is effectively limited to be parallel to the clay layers. Previous experimental studies of $\mathrm{H}_{2} \mathrm{O}$ diffusion in the interlayers of Na-fluorhectorite measured twodimensional diffusion coefficients of $2.8 \pm 0.4 \times 10^{-10} \mathrm{~m}^{2} / \mathrm{s}$ for the 1 WL hydrate ${ }^{57,60}$ and $3.5-$ 
$8.7 \times 10^{-10} \mathrm{~m}^{2} / \mathrm{s}$ for the $2 \mathrm{WL}$ hydrate. ${ }^{57,58,60}$ A recent computational study gave two-dimensional $\mathrm{H}_{2} \mathrm{O}$ diffusion coefficients of $2.71-6.2 \times 10^{-10} \mathrm{~m}^{2} / \mathrm{s}$ for the 1 WL hydrate for Nafluorhectorite. ${ }^{67}$ These values are similar to recent experimental studies of $\mathrm{H}_{2} \mathrm{O}$ diffusion in Namontmorillonite, which showed values $2.5 \times 10^{-10} \mathrm{~m}^{2} / \mathrm{s}$ and $8.0 \times 10^{-10} \mathrm{~m}^{2} / \mathrm{s}$ for the 1 WL hydrate and $5.0 \times 10^{-10} \mathrm{~m}^{2} / \mathrm{s}$ and $10.0 \times 10^{-10} \mathrm{~m}^{2} / \mathrm{s}$ for the $2 \mathrm{WL}$ hydrate. ${ }^{65}$ In addition, a recent computational investigation of the same systems gave values of $2.5 \times 10^{-10} \mathrm{~m}^{2} / \mathrm{s}$ and $3.8 \times 10^{-10}$ $\mathrm{m}^{2} / \mathrm{s}$ for the $1 \mathrm{WL}$ and $8.1 \times 10^{-10} \mathrm{~m}^{2} / \mathrm{s}$ and $10.0 \times 10^{-10} \mathrm{~m}^{2} / \mathrm{s}$ for the $2 \mathrm{WL}$ hydrates. ${ }^{65}$ Many other studies have measured or calculated diffusion coefficients for interlayer water, but they either report values for 3D diffusion or do not specify which type the value represents.

Comparison between our results and those of previous studies of hectorites shows that although the systems in the different studies have different $\mathrm{H}_{2} \mathrm{O} / \mathrm{Na}^{+}$and $\mathrm{Na}^{+} /$unit cell ratios, the diffusion coefficients of the nano-confined $\mathrm{Na}^{+}$ions and $\mathrm{H}_{2} \mathrm{O}$ molecules are not significantly different for similar hydration structures. Our 1 and $2 \mathrm{WL}$ hydrates have 3 and $10 \mathrm{H}_{2} \mathrm{O} / 8 \mathrm{Si}$ (= 3 and $10 \mathrm{H}_{2} \mathrm{O} / \mathrm{Na}^{+}$), respectively. Recent experimental and computational studies of Nafluorhectorite hydration identified 1 WL hydrates with $\mathrm{H}_{2} \mathrm{O} / 8 \mathrm{Si}=2.9-3.2$ and $3.2-4\left(\mathrm{H}_{2} \mathrm{O} / \mathrm{Na}^{+}\right.$ $=3.6-4.1$ and $4-5$ ), respectively..$^{57,60,67}$ A previous experimental study of Na-fluorhectorite hydration identified a 2 WL hydrate with $5.7-5.9 \mathrm{H}_{2} \mathrm{O} / 8 \mathrm{Si}\left(\mathrm{H}_{2} \mathrm{O} / \mathrm{Na}^{+}=7.1-7.4\right) .{ }^{57}$ Nonetheless, our calculated diffusion coefficient for the $2 \mathrm{WL}$ hydrate $\left(\mathrm{H}_{2} \mathrm{O} / 8 \mathrm{Si}=10\right)$ compares well with previous experimental values. ${ }^{57,58,60}$

All of the diffusion coefficients in the present work as well as those from previous studies indicate that nano-confined water in smectite interlayers diffuses more slowly than in the bulk. Previous experimental studies of self-diffusion of bulk water utilizing the diaphragm cell technique ${ }^{157}$ and NMR pulse-gradient spin echo approaches ${ }^{158}$ at $298 \mathrm{~K}$ gave values of $2.3 \times 10^{-9}$ 
$\mathrm{m}^{2} / \mathrm{s}$. Computational studies employing the original, refined, and flexible versions of the SPC water potential give values of $3.6-5.3 \times 10^{-9} \mathrm{~m}^{2} / \mathrm{s},{ }^{159} 4.20 \pm 0.08 \times 10^{-9} \mathrm{~m}^{2} / \mathrm{s},{ }^{160}$ and $6.1 \pm 0.2 \mathrm{x}$ $10^{-9} \mathrm{~m}^{2} / \mathrm{s},{ }^{135}$ respectively. Thus, the diffusion of $\mathrm{H}_{2} \mathrm{O}$ molecules in the $2 \mathrm{WL}$ hydrate of Nahectorite is approximately 4 to 5 times slower than the bulk solution, in accord with suggestions of previous authors. ${ }^{57,60,67,102,109,115}$

\subsection{Geometric and Energetic Environments in the $\mathrm{Na}^{+}$Coordination Shell}

The free energy profiles, $F(\theta)$, associated with the $\mathrm{SN}-\mathrm{Na}-\mathrm{O}_{\mathrm{H} 20}$ angle, $\theta$, computed from metadynamics calculations for the $1 \mathrm{WL}$ and $2 \mathrm{WL}$ systems $\left(\mathrm{H}_{2} \mathrm{O} / \mathrm{Na}^{+}=3\right.$ and 10 , respectively; Figure 10) are consistent with the MD results and provide a quantitative energy landscape for diffusional motion. The possible values of $\theta$ range from $0^{\circ}-180^{\circ} \cdot \theta=0^{\circ}$ and $\theta=180^{\circ}$ correspond to the parallel and anti-parallel orientations of the $\mathrm{Na}-\mathrm{O}_{\mathrm{H} 2 \mathrm{O}}$ bond vector with respect to the SN, respectively. In these orientations, the tagged $\mathrm{H}_{2} \mathrm{O}$ molecule lies closer to the clay surface than the $\mathrm{Na}^{+}$ion. $\theta=90^{\circ}$ indicates that the tagged $\mathrm{O}_{\text {н2о }}$ and the $\mathrm{Na}^{+}$ion lie on a plane parallel to the clay surface. The free energy profile for the $3 \mathrm{H}_{2} \mathrm{O} / \mathrm{Na}^{+}$sample consists of a single minimum at $\theta=90^{\circ}$, consistent with the $1 \mathrm{WL}$ structure with $\mathrm{Na}^{+}$ions and $\mathrm{O}_{\mathrm{H} 2 \mathrm{O}}$ lying in a single plane parallel to the clay surface. At this hydration level, the free energy increases with deviation of $\theta$ from $90^{\circ}$ leading to the angular states with $\theta>135^{\circ}$ and $\theta<45^{\circ}$ that are $\sim 19.0 \mathrm{~kJ} / \mathrm{mol}$ higher in energy than the minimum at $\theta=90^{\circ}$. This value is the activation energy for a $\mathrm{H}_{2} \mathrm{O}$ molecule to approach the clay surface from the $\mathrm{Na}^{+}-\mathrm{H}_{2} \mathrm{O}$ layer.

In contrast to the $1 \mathrm{WL}$ structure, for the $2 \mathrm{WL}$ system at $10 \mathrm{H}_{2} \mathrm{O} / \mathrm{Na}^{+}$, the computed free energy profile has two minima: one at $\theta=46^{\circ}$ and the other at $\theta=124^{\circ}$. These minima are nearly iso-energetic and correspond to the two layers of $\mathrm{H}_{2} \mathrm{O}$ molecules formed at this composition. The activation energies for a $\mathrm{H}_{2} \mathrm{O}$ molecule to jump between two WLs and between a WL and the 
nearest clay surface are $\sim 3.3 \mathrm{~kJ} / \mathrm{mol}$ and $\sim 11-12 \mathrm{~kJ} / \mathrm{mol}$, respectively. The thermal energy at room temperature $(\sim 2.5 \mathrm{~kJ} / \mathrm{mol})$ is sufficient to overcome the activation barrier for movement between the two WLs. Thus, such hopping is likely to be one of the fast dynamical (out-ofplane) processes occurring in the clay interlayer galleries. The relaxation time estimated using transition state theory ${ }^{161}$ is 0.42 ps, consistent with the fast motion limit for site hopping predicted by out ${ }^{2} \mathrm{H}$ NMR results. ${ }^{46}$

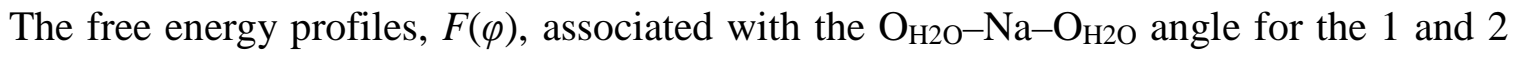
WL $\left(\mathrm{H}_{2} \mathrm{O} / \mathrm{Na}^{+}=3\right.$ and 10$)$ systems provide energetic insights in to the first hydration shell structure around $\mathrm{Na}^{+}$ions and the energy penalty for $\mathrm{H}_{2} \mathrm{O}$ molecules to rearrange within this shell (Figure 11). The reaction coordinate $\varphi$ is defined by a selected pair of $\mathrm{H}_{2} \mathrm{O}$ molecules in the first coordination shell of a tagged $\mathrm{Na}^{+}$ion. The free energy profile for the $10 \mathrm{H}_{2} \mathrm{O} / \mathrm{Na}^{+}$system consists of two minima: one at $\varphi=80^{\circ}$ and the other at $\varphi=165^{\circ}$. The minimum at $\varphi=165^{\circ}$ is $\sim 3.0 \mathrm{~kJ} / \mathrm{mol}$ is less stable than the state at $\varphi=80^{\circ}$.

The first hydration shell of a $\mathrm{Na}^{+}$ion in bulk $\mathrm{NaCl}$ solution adopts an octahedral geometry with two equatorial and four axial $\mathrm{O}_{\mathrm{H} 2 \mathrm{O}}$ atoms. ${ }^{118,162}$ In this ideal octahedral geometry, $\varphi$ can be either $90^{\circ}$, here referred to as the orthogonal- or O-state, or $180^{\circ}$, referred to as the anti-

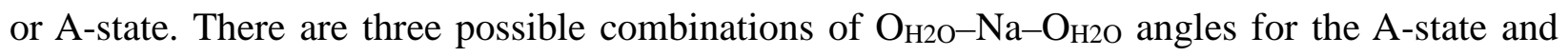
twelve for the O-state. That is, the population of O-state is four times that of the A-state. Using these populations and Boltzmann statistics, the difference in energy between these two states can be estimated to be $\sim 3.3 \mathrm{~kJ} / \mathrm{mol}$. This value is almost equal to the difference in energy between the states with $\varphi=80^{\circ}$ and $\varphi=165^{\circ}$ for the $10 \mathrm{H}_{2} \mathrm{O} / \mathrm{Na}^{+}$system. However, the values of $\varphi$ corresponding to the minima deviate significantly from those expected for an ideal octahedral structure. This deviation and the breadth of the free-energy wells indicate that the first solvation 
shell around a $\mathrm{Na}^{+}$ion adopts a distorted (compressed) octahedral structure in the interlayer, which is tilted with respect to the surface normal. The distortion from the ideal octahedral geometry can be attributed to the interactions of the cations and water molecules with the clay surfaces. $F(\varphi)$ for the $3 \mathrm{H}_{2} \mathrm{O} / \mathrm{Na}^{+}$system (Figure $11 \mathrm{~b}$ ) also exhibits two minima: one at $\varphi=80^{\circ}$ and the other at $\varphi=168^{\circ}$. The difference in energy between these two states is $\sim 2.5 \mathrm{~kJ} / \mathrm{mol}$. If the first solvation shell around $\mathrm{Na}^{+}$were square-planar in geometry, $F(\varphi)$ would show minima at $\varphi=$ $90^{\circ}$ for the O-state and $\varphi=180^{\circ}$ for the A-state. Since there are two possible combinations of $\mathrm{O}_{\mathrm{H} 2 \mathrm{O}}-\mathrm{Na}-\mathrm{O}_{\mathrm{H} 2 \mathrm{O}}$ angles for the A-state and four for the O-state in a symmetric square-planar geometry, the A-state is expected to be $\sim 1.7 \mathrm{~kJ} / \mathrm{mol}$ less stable than the O-state, based on Boltzmann statistics. This is consistent with the difference in energy between states with $\varphi=80^{\circ}$ and $\varphi=168^{\circ}$. The difference between these angles and the ideal ones is a measure of the site distortion related to nano-confinement.

\section{Conclusions}

The interlayer hydration of Na-hydroxyhectorite is investigated via classical MD simulations and metadynamics calculations over a wide range of hydration states from completely dry hectorite (no $\mathrm{H}_{2} \mathrm{O}$ molecules) to greater than that needed to produce a two-waterlayer hydrate. Minima in the hydration energy indicate stability of 1, 1.5, and 2 WL hydrates at $\mathrm{H}_{2} \mathrm{O} / \mathrm{Na}^{+}=3,5.5$, and 10 , respectively. This is the first computational investigation to identify a stable $1.5 \mathrm{WL}$ hydrate for Na-hectorite. In the $1 \mathrm{WL}$ hydrate, $\mathrm{Na}^{+}$ions are partially coordinated by both $\mathrm{O}_{\mathrm{MIN}}$ and $\mathrm{O}_{\mathrm{H} 2 \mathrm{O}}$, the $\mathrm{HB}$ network is not entirely formed for $\mathrm{H}_{2} \mathrm{O}$ molecules in the interlayer, and $\mathrm{Na}^{+}$ions and $\mathrm{H}_{2} \mathrm{O}$ molecules move only slightly from their initial positions in the simulations. The development of an extended $\mathrm{HB}$ network between $\mathrm{H}_{2} \mathrm{O}$ molecules and $\mathrm{O}_{\text {MIN }}$ 
atoms within the interlayer continues as hydration increases, such that in the $2 \mathrm{WL}$ hydrate $\mathrm{Na}^{+}$ ions are coordinated by $6.0 \mathrm{H}_{2} \mathrm{O}$, as in bulk solution. The orientation of $\mathrm{H}_{2} \mathrm{O}$ molecules with respect to the clay surface and the $\mathrm{H}_{2} \mathrm{O}$ and $\mathrm{Na}^{+}$diffusion coefficients also change systematically with increasing hydration. The calculated basal spacings and the calculated orientation of the $\mathrm{H}_{2} \mathrm{O}$ molecules with respect to the clay layers are in excellent agreement with the values determined from X-ray diffraction analyses and ${ }^{2} \mathrm{H}$ NMR spectroscopy, respectively. The orientations support the dynamical model involving simultaneous fast librational motion with $\mathrm{C}_{2}$ symmetry and site hopping with $\mathrm{C}_{3}$ symmetry. Metadynamics calculations yield activation energies for site interlayer hopping and show that the correlation times for site hopping in the 2 WL hydrate are also consistent with this method.

\section{Acknowledgements}

The authors thank Dr. Jeffery Greathouse of Sandia National Laboratories assistance with data analysis and Dr. Moumita Saharay of the Department of Chemistry at Michigan State University as well as Dr. Randall Cygan of Sandia National Laboratories for meaningful discussions. The calculations in this work were performed using computational resources at the National Energy Research Scientific Computing Center (NERSC), which is supported by the Office of Science of the U.S. Department of Energy under Contract No. DE-AC02-05CH11231, through Energy Research Computing Allocations Process (ERCAP) Request \#84279; and through the Extreme Science and Engineering Discovery Environment (XSEDE), which is supported by National Science Foundation grant number OCI-1053575, via Research Allocation TG-EAR990003N. Financial support of this work was provided by the U. S. Department of Energy, Office of Basic Energy Sciences under Grants No. DE-PS02-09ER09-02, DE-FG02- 
10ER16128, and DE-FG02-08ER15929. AGK acknowledges additional support by the industrial chair "Storage and Management of Nuclear Waste" at the École des Mines de Nantes, France, funded by ANDRA, Areva, and EDF. 


\section{References}

(1) Wagai, R.; Mayer, L. M. Geochim. Cosmochim. Ac. 2007, 71, 25.

(2) Sanderman, J.; Amundson, R. Biogeochemistry 2009, 92, 41.

(3) Moni, C.; Rumpel, C.; Virto, I.; Chabbi, A.; Chenu, C. Eur. J. Soil Biol. 2010, 61, 958.

(4) Kaszuba, J. P.; Janecky, D. R.; Snow, M. G. Chem. Geol. 2005, 217, 277.

(5) Credoz, A.; Bildstein, O.; Jullien, M.; Raynal, J.; Petronin, J.-C.; Lillo, M.; Pozo, C.; Geniaut, G. Energy Procedia 2009, 1, 3445.

(6) McGrail, B. P.; Schaef, H. T.; Glezakou, V. A.; Dang, L. X.; Owen, A. T. Energy Procedia. 2009, 1, 3415.

(7) Rimmele, G.; Barlet-Gouedard, V.; Renard, F. Oil Gas Sci. Technol. 2010, 65, 565.

(8) Shao, H. B.; Ray, J. R.; Jun, Y. S. Environ. Sci. Technol. 2010, 44, 5999.

(9) O'Day, P. A. Rev. Geophys. 1999, 37, 249.

(10) Koretsky, C. J. Hydrol. 2000, 230, 127.

(11) Sparks, D. L. Geoderma 2001, 100, 303.

(12) Szenknect, S.; Ardois, C.; Dewiere, L.; Gaudet, J. P. J. Contam. Hydrol. 2008, 100, 47.

(13) Meakin, P.; Tartakovsky, A. M. Rev. Geophys. 2009, 47, 47.

(14) Brown, G. E.; Calas, G. C. R. Geosci. 2011, 343, 90.

(15) Marklund, L.; Simic, E.; Worman, A.; Dverstorp, B. The impact of different geological parameters on transport of radionuclides. In Proceedings of 2006 International HIghLevel Radioactive Waste Management Conference; American Nuclear Society: April 30 - May 4, 2006, Las Vegas, NV, USA, p. 369-373.

(16) Bodvarsson, G. S.; Boyle, W.; Patterson, R.; Williams, D. J. Contam. Hydrol. 1999, 38, 3.

(17) Long, J. C. S.; Ewing, R. C. Annu. Rev. Earth Pl. Sc. 2004, 32, 363.

(18) Boek, E. S.; Coveney, P. V.; Skipper, N. T. J. Am. Chem. Soc. 1995, 117, 12608.

(19) Smith, D. E. Langmuir 1998, 14, 5959.

(20) Kalinichev, A. G.; Kirkpatrick, R. J.; Cygan, R. T. Am. Mineral. 2000, 85, 1046. 
(21) Wang, J. W.; Kalinichev, A. G.; Kirkpatrick, R. J.; Hou, X. Q. Chem. Mater. 2001, 13, 145.

(22) Park, S. H.; Sposito, G. Phys. Rev. Lett. 2002, 89.

(23) Boek, E. S.; Sprik, M. J. Phys. Chem. B 2003, 107, 3251.

(24) Wang, J. W.; Kalinichev, A. G.; Amonette, J. E.; Kirkpatrick, R. J. Am. Mineral. 2003, 88, 398.

(25) Cygan, R. T.; Liang, J. J.; Kalinichev, A. G. J. Phys. Chem. B 2004, 108, 1255. 222, 517.

(26) Wang, J. W.; Kalinichev, A. G.; Kirkpatrick, R. J. Earth Planet. Sc. Lett. 2004,

(27) Wang, J. W.; Kalinichev, A. G.; Kirkpatrick, R. J. Geochim. Cosmochim. Ac. 2004, 68, 3351.

(28) Kirkpatrick, R. J.; Kalinichev, A. G.; Wang, J. Mineral. Mag. 2005, 69, 289.

(29) Kirkpatrick, R. J.; Kalinichev, A. G.; Wang, J.; Amonette, J. E. Molecular modeling of the vibrational spectra of interlayer and surface species of layered double hydroxides. In The application of vibrational spectroscopy to Clay Miner.; CMS Workshop Lectures, Clay Miner. Society, 2005; Vol. 13; pp 239. 14308.

(30) Wang, J. W.; Kalinichev, A. G.; Kirkpatrick, R. J. J. Phys. Chem. B 2005, 109,

(31) Wang, J. W.; Kalinichev, A. G.; Kirkpatrick, R. J.; Cygan, R. T. J. Phys. Chem. B 2005, 109, 15893.

(32) Wang, J. W.; Kalinichev, A. G.; Kirkpatrick, R. J. Geochim. Cosmochim. Ac. 2006, 70, 562. $37,337$.

(33) Kalinichev, A. G.; Wang, J. W.; Kirkpatrick, R. J. Cement Concrete Res. 2007,

(34) Cygan, R. T.; Greathouse, J. A.; Heinz, H.; Kalinichev, A. G. J. Mater. Chem. 2009, 19, 2470. 11077.

(35) Wang, J. W.; Kalinichev, A. G.; Kirkpatrick, R. J. J. Phys. Chem. C 2009, 113,

(36) Kalinichev, A. G.; Kumar, P. P.; Kirkpatrick, R. J. Philos. Mag. 2010, 90, 2475.

(37) Sakuma, H.; Kawamura, K. Geochim. Cosmochim. Ac. 2011, 75, 63. 96, 301.

(38) Smrcok, L.; Rieder, M.; Kolesnikov, A. I.; Granroth, G. E. Am. Mineral. 2011,

(39) Weiss, C. A.; Kirkpatrick, R. J.; Altaner, S. P. Am. Mineral. 1990, 75, 970. 

54, 1655.

(40) Weiss, C. A.; Kirkpatrick, R. J.; Altaner, S. P. Geochim. Cosmochim. Ac. 1990,

(41) Komadel, P.; Madejova, J.; Janek, M.; Gates, W. P.; Kirkpatrick, R. J.; Stucki, J. W. Clay Clay Miner. 1996, 44, 228.

(42) Bowers, G. M.; Bish, D. L.; Kirkpatrick, R. J. J. Phys. Chem. C 2008, 112, 6430.

(43) Bowers, G. M.; Bish, D. L.; Kirkpatrick, R. J. Langmuir 2008, 24, 10240.

(44) Tenorio, R. P.; Alme, L. R.; Engelsberg, M.; Fossum, J. O.; Hallwass, F. J. Phys. Chem. C 2008, 112, 575. 9703.

(45) Tenorio, R. P.; Engelsberg, M.; Fossum, J. O.; da Silva, G. J. Langmuir 2010, 26,

(46) Bowers, G. M.; Singer, J. W.; Bish, D. L.; Kirkpatrick, R. J. J. Phys. Chem. C 2011, 115, 23395.

(47) Kagunya, W. W. J. Phys. Chem. 1996, 100, 327.

(48) Skipper, N. T.; Williams, G. D.; de Siqueira, A. V. C.; Lobban, C.; Soper, A. K. Clay Miner. 2000, 35, 283.

(49) Swenson, J.; Bergman, R.; Howells, W. S. J. Chem. Phys. 2000, 113, 2873.

(50) Swenson, J.; Bergman, R.; Longeville, S.; Howells, W. S. Physica B 2001, 301, 28.

(51) Marry, V.; Turq, P. J. Phys. Chem. B 2003, 107, 1832.

(52) Malikova, N.; Cadene, A.; Marry, V.; Dubois, E.; Turq, P.; Zanotti, J. M.; Longeville, S. Chem. Phys. 2005, 317, 226.

82.

(53) Marry, V.; Malikova, N.; Turq, P.; Giffaut, E. Actual. Chimique 2005, 285-286,

(54) Devineau, K.; Bihannic, I.; Michot, L.; Villieras, F.; Masrouri, F.; Cuisinier, O.; Fragneto, G.; Michau, N. Appl. Clay Sci. 2006, 31, 76.

(55) Malikova, N.; Cadene, A.; Marry, V.; Dubois, E.; Turq, P. J. Phys. Chem. B 2006, $110,3206$. 141,65 .

(56) Gonzalez, F.; Juranyi, F.; Van Loon, L.; Gimmi, T. Eur. Phys. J.-Spec. Top. 2007,

(57) Malikova, N.; Cadene, A.; Dubois, E.; Marry, V.; Durand-Vidal, S.; Turq, P.; Breu, J.; Longeville, S.; Zanotti, J. M. J. Phys. Chem. C 2007, 111, 17603.

(58) Malikova, N.; Longeville, S.; Zanotti, J. M.; Dubois, E.; Marry, V.; Turq, P.; Ollivier, J. Phys. Rev. Lett. 2008, 101, 265901. 
(59) Mamontov, E.; Wesolowski, D. J.; Vlcek, L.; Cummings, P. T.; Rosenqvist, J.; Wang, W.; Cole, D. R. J. Phys. Chem. C 2008, 112, 12334.

(60) Marry, V.; Malikova, N.; Cadene, A.; Dubois, E.; Durand-Vidal, S.; Turq, P.; Breu, J.; Longeville, S.; Zanotti, J. M. J. Phys.-Condens. Mat. 2008, 20, 104205.

(61) Sanchez, F. G.; Juranyi, F.; Gimmi, T.; Van Loon, L.; Unruh, T.; Diamond, L. W. J. Chem. Phys. 2008, 129, 174706.

(62) Bihannic, I.; Delville, A.; Deme, B.; Plazanet, M.; Villieras, F.; Michot, L. J. Clay Swelling: New Insights from Neutron-Based Techniques. In Neutron Applications in Earth, Energy and Environmental Sciences; Springer: New York, 2009; pp 521.

(63) Cole, D. R.; Mamontov, E.; Rother, G. Structure and Dynamics of Fluids in Microporous and Mesoporous Earth and Engineered Materials. In Neutron Applications in Earth, Energy and Environmental Sciences, 2009; pp 547.

(64) Sobolev, O.; Le Forestier, L.; Gonzalez, M. A.; Russina, M.; Kemner, E.; Cuello, G. J.; Charlet, L. J. Phys. Chem. C 2009, 113, 13801.

(65) Malikova, N.; Dubois, E.; Marry, V.; Rotenberg, B.; Turq, P. Z. Phys. Chem.2010, 224, 153.

(66) Sobolev, O.; Buivin, F. F.; Kemner, E.; Russina, M.; Beuneu, B.; Cuello, G. J.; Charlet, L. Chem. Phys. 2010, 374, 55.

(67) Marry, V.; Dubois, E.; Malikova, N.; Durand-Vidal, S.; Longeville, S.; Breu, J. Environ. Sci. Technol. 2011, 45, 2850.

(68) Laird, D. A. Appl. Clay Sci. 2006, 34, 74.

(69) Johnston, C. T. Clay Miner. 2010, 45, 245.

(70) Kliewer, K. E.; Morra, M. J. Soil Sci. Soc. Am. J. 1998, 62, 916.

(71) Boulet, P.; Bowden, A. A.; Coveney, P. V.; Whiting, A. J. Mater. Chem. 2003, $13,2540$.

(72) Hartzell, C. J.; Cygan, R. T.; Nagy, K. L. J. Phys. Chem. A 1998, 102, 6722.

(73) Mastalir, A.; Szollosi, G.; Kiraly, Z.; Razga, Z. Appl. Clay Sci. 2002, 22, 9.

(74) Frey, S. T.; Hutchins, B. M.; Anderson, B. J.; Schreiber, T. K.; Hagerman, M. E. Langmuir 2003, 19, 2188.

(75) Hensen, E. J. M.; Smit, B. J. Phys. Chem. B 2002, 106, 12664.

(76) Smith, D. E.; Wang, Y.; Whitley, H. D. Fluid Phase Equilibr. 2004, 222, 189.

(77) Whitley, H. D.; Smith, D. E. J. Chem. Phys. 2004, 120, 5387. 
(78) Kumar, P. P.; Kalinichev, A. G.; Kirkpatrick, R. J. J. Phys. Chem. B 2006, 110,

(79) Kumar, P. P.; Kalinichev, A. G.; Kirkpatrick, R. J. J. Phys. Chem. C 2007, 111, 13517.

(80) Abraham, F. F. J. Chem. Phys. 1978, 68, 3713.

(81) Salles, F.; Bildstein, O.; Douillard, J. M.; Jullien, M.; Raynal, J.; Van Damme, H. Langmuir 2010, 26, 5028. 98, 2668.

(82) Ukrainczyk, L.; Chibwe, M.; Pinnavaia, T. J.; Boyd, S. A. J. Phys. Chem. 1994,

(83) Siantar, D. P.; Fripiat, J. J. J. Colloid Inter. Sci. 1995, 169, 400.

(84) AnnabiBergaya, F.; EstradeSzwarckopf, H.; VanDamme, H. J. Phys. Chem. 1996, $100,4120$.

(85) Kaviratna, P. D.; Pinnavaia, T. J.; Schroeder, P. A. J. Phys. Chem. Soilds 1996, 57, 1897.

(86) Ukrainczyk, L.; Smith, K. A. Environ. Sci. Technol. 1996, 30, 3167.

(87) Jozja, N.; Baillif, P.; Touray, J. C.; Muller, F.; Clinard, C. Eur. J. Mineral. 2006, 18, 361.

(88) Karmous, M. S.; Oueslati, W.; Ben Rhaiem, H.; Robert, J. L.; Amara, A. B. H. Z. Kristallogr. 2007, 26, 503.

(89) Akbar, S.; Pukala, M.; Walton, K. S. J. Chem. Soc. Pakistan 2008, 30, 546.

(90) Karmous, M. S.; Ben Rhaiem, H.; Robert, J. L.; Lanson, B.; Amara, A. B. H. Appl. Clay Sci. 2009, 46, 43.

(91) Kalo, H.; Milius, W.; Breu, J. RSC Adv. 2012, 2, 8452.

(92) Hou, X. Q.; Bish, D. L.; Wang, S. L.; Johnston, C. T.; Kirkpatrick, R. J. Am. Mineral. 2003, 88, 167.

(93) Iyi, N.; Fujii, K.; Okamoto, K.; Sasaki, T. Appl. Clay Sci. 2007, 35, 218.

(94) Morodome, S.; Kawamura, K. Clay Clay Miner. 2009, 57, 150.

(95) Kalinichev, A. G.; Kirkpatrick, R. J. Chem. Mater. 2002, 14, 3539.

(96) Skipper, N. T.; Chang, F. R. C.; Sposito, G. Clay Clay Miner. 1995, 43, 285.

(97) Skipper, N. T.; Sposito, G.; Chang, F. R. C. Clay Clay Miner. 1995, 43, 294.

(98) Sposito, G.; Park, S. H.; Sutton, R. Clay Clay Miner. 1999, 47, 192. 
(99) Young, D. A.; Smith, D. E. J. Phys. Chem. B 2000, 104, 9163.

(100) Titiloye, J. O.; Skipper, N. T. Mol. Phys. 2001, 99, 899.

(101) Marry, V.; Turq, P.; Cartailler, T.; Levesque, D. J. Chem. Phys. 2002, 117, 3454.

(102) Sutton, R.; Sposito, G. Geochem. T. 2002, 3, 73.

(103) Chatterjee, A.; Ebina, T.; Onodera, Y.; Mizukami, F. J. Chem. Phys. 2004, 120, 3414.

(104) Malikova, N.; Marry, V.; Dufreche, J. F.; Simon, C.; Turq, P.; Giffaut, E. Mol. Phys. 2004, 102, 1965.

(105) Tambach, T. J.; Hensen, E. J. M.; Smit, B. J. Phys. Chem. B 2004, 108, 7586.

(106) Meleshyn, A.; Bunnenberg, C. J. Chem. Phys. 2005, 122, 034705.

(107) Liu, X. D.; Lu, X. C. Angew. Chem. Int. Edit. 2006, 45, 6300.

(108) Na, P.; Zhang, F.; Li, Y.-N. Acta Phys.-Chim. Sin. 2006, 22, 1137.

(109) Skipper, N. T.; Lock, P. A.; Titiloye, J. O.; Swenson, J.; Mirza, Z. A.; Howells, W. S.; Fernandez-Alonso, F. Chem. Geol. 2006, 230, 182. 1223.

(110) Tambach, T. J.; Bolhuis, P. G.; Hensen, E. J. M.; Smit, B. Langmuir 2006, 22,

(111) Wang, J.; Zeng, F. G.; Wang, J. X. Acta Chim. Sinica 2006, 64, 1654.

(112) Kosakowski, G.; Churakov, S. V.; Thoenen, T. Clay Clay Miner. 2008, 56, 190.

(113) Liu, X.; Lu, X.; Wang, R.; Zhou, H. Geochim. Cosmochim. Ac. 2008, 72, 1837.

(114) Mignon, P.; Ugliengo, P.; Sodupe, M.; Hernandez, E. R. Phys. Chem. Chem. Phys. 2010, 12, 688.

(115) Rotenberg, B.; Marry, V.; Malikova, N.; Turq, P. J. Phys.-Condens. Mat. 2010, 22, 28114.

(116) Tao, L.; Tian, X. F.; Yu, Z.; Tao, G. Chin. Physics B 2010, 19, 109101.

(117) Zheng, Y.; Zaoui, A.; Shahrour, I. Am. Mineral. 2010, 95, 1493.

(118) Sposito, G.; Skipper, N. T.; Sutton, R.; Park, S. H.; Soper, A. K.; Greathouse, J. A. P. Natl. Acad. Sci. USA 1999, 96, 3358.

(119) Teich-McGoldrick, S. L.; Greathouse, J. A.; Cygan, R. T. J. Phys. Chem. C 2012, 116, 15099. 
(120) Zeitler, T. R.; Greathouse, J. A.; Cygan, R. T. Phys. Chem. Chem. Phys. : PCCP 2012, 14, 1728.

(121) Rinnert, E.; Carteret, C.; Humbert, B.; Fragneto-Cusani, G.; Ramsay, J. D. F.; Delville, A.; Robert, J. L.; Bihannic, I.; Pelletier, M.; Michot, L. J. J. Phys. Chem. B 2005, 109, 23745.

(122) Ferrage, E.; Sakharov, B. A.; Michot, L. J.; Delville, A.; Bauer, A.; Lanson, B.; Grangeon, S.; Frapper, S.; Jimenez-Ruiz, M.; Cuello, G. J. J. Phys. Chem. C 2011, 115, 1867.

(123) Shroll, R. M.; Smith, D. E. J. Chem. Phys. 1999, 111, 9025.

(124) Breu, J.; Seidl, W.; Stoll, A. Z. Anorg. Allg. Chem. 2003, 629, 503.

(125) Anthony, J. A.; Bideaux, R. A.; Bladh, K. W.; Nichols, M. C. Handbook of Mineralogy; Mineralogical Society of America: Chantilly, VA, 2001.

(126) Ahn, W. Y.; Kalinichev, A. G.; Clark, M. M. J. Membrane Sci. 2008, 309, 128.

(127) Kerisit, S.; Liu, C. X.; Ilton, E. S. Geochim. Cosmochim. Ac. 2008, 72, 1481.

(128) Meleshyn, A. J. Phys. Chem. C 2008, 112, 14495.

(129) Wander, M. C. F.; Clark, A. E. J. Phys. Chem. C 2008, 112, 19986.

(130) Malani, A.; Ayappa, K. G. J. Phys. Chem. B 2009, 113, 1058.

(131) Malani, A.; Ayappa, K. G.; Murad, S. J. Phys. Chem. B 2009, 113, 13825.

(132) Argyris, D.; Ashby, P. D.; Striolo, A. ACS NANO 2011, 5, 2215.

(133) Argyris, D.; Ho, T. A.; Cole, D. R.; Striolo, A. J. Phys. Chem. C 2011, 115, 2038.

(134) Ho, T. A.; Argyris, D.; Papavassiliou, D. V.; Striolo, A.; Lee, L. L.; Cole, D. R. Molecular Simulat. 2011, 37, 172.

(135) Teleman, O.; Jonsson, B.; Engstrom, S. Mol. Phys. 1987, 60, 193.

(136) Berendsen, H. J. C.; Postma, J. P. M.; van Gunsteren, W. F.; Hermans, J. Interaction Models for Water in Relation to Protein Hydration. In Intermolecular Forces; Pulllman, B., Ed.; Reidel: Dordrecht, 1981; pp 331.

(137) Jorgensen, W. L.; Chandrasekhar, J.; Madura, J. D.; Impey, R. W.; Klein, M. L. J. Chem. Phys. 1983, 79, 926.

(138) Mizan, T. I.; Savage, P. E.; Ziff, R. M. J. Phys. Chem. 1994, 98, 13067.

(139) Robinson, G. W.; Zhu, S.-B.; Singh, S.; Evans, M. W. Water in Biology, Chemistry and Physics. Experimental Overviews and Computational Methologies; World Scientific Publishing Co. Pte. Ltd.: Singapore, 1996; Vol. 9. 
(140) Jorgensen, W. L.; Jenson, C. J. Comput. Chem. 1998, 19, 1179.

(141) Wallqvist, A.; Mountain, R. D. Molecular models of water: Derivation and Description. In Reviews in Computational Chemistry; Lipkowitz, K. B., Boyd, D. B., Eds.; Wiley-WCH: New York, 1999; Vol. 13; pp 183.

(142) Guillot, B. J. Mol. Liq. 2002, 101, 219.

(143) DL_POLY Classic Molecular Dynamics Simulation Package, http://www.ccp5.ac.uk/DL_POLY_CLASSIC/.

(144) Smith, W.; Forester, T. R.; Todorov, I. T. The DL_POLY Classic User Manual; Daresbury Laboratory, United Kingdom.

(145) Hoover, W. G. Phys. Rev. A 1985, 31, 1695.

(146) Cygan, R. T.; Greathouse, J. A. 2011, personal communication.

(147) Phillips, J. C.; Braun, R.; Wang, W.; Gumbart, J.; Tajkhorshid, E.; Villa, E.; Chipot, C.; Skeel, R. D.; Kale, L.; Schulten, K. J. Comput. Chem. 2005, 26, 1781. 35.

(148) Henin, J.; Fiorin, G.; Chipot, C.; Klein, M. L. J. Chem. Theory Comput. 2009, 6,

(149) Molina-Montes, E.; Donadio, D.; Hernandez-Laguna, A.; Sainz-Diaz, C. I.; Parrinello, M. J. Phys. Chem. B 2008, 112, 7051.

(150) Luzar, A.; Chandler, D. Phys. Rev. Lett. 1996, 76, 928.

(151) Wilson, J.; Cuadros, J.; Cressey, G. Clay Clay Miner. 2004, 52, 180.

(152) Ferrage, E.; Lanson, B.; Sakharov, B. A.; Drits, V. A. Am. Mineral. 2005, 90, 1358.

(153) Jimenez-Ruiz, M.; Ferrage, E.; Delville, A.; Michot, L. J. J. Phys. Chem. A 2012, 116, 2379.

(154) Smith, D. E.; Dang, L. X. J. Chem. Phys. 1994, 100, 3757.

(155) Koneshan, S.; Rasaiah, J. C. J. Chem. Phys. 2000, 113, 8125.

(156) Bondarenko, G. V.; Gorbaty, Y. E.; Okhulkov, A. V.; Kalinichev, A. G. J. Phys. Chem. A 2006, 110, 4042.

(157) Mills, R. J. Phys. Chem. 1973, 77, 685.

(158) Price, W. S.; Ide, H.; Arata, Y. J. Phys. Chem. A 1999, 103, 448.

(159) van der Spoel, D.; van Maaren, P. J.; Berendsen, H. J. C. J. Chem. Phys. 1998, $108,10220$. 
(160) Mark, P.; Nilsson, L. J. Phys. Chem. A 2001, 105, 9954.

(161) Garcia-Viloca, M.; Gao, J.; Karplus, M.; Truhlar, D. G. Science 2004, 303, 186.

(162) Ohtaki, H.; Radnai, T. Chem. Rev. 1993, 93, 1157. 
Table 1: Average $\mathrm{SN}-\mathrm{Na}-\mathrm{O}_{\mathrm{H} 2 \mathrm{O}}\left(\theta,{ }^{\circ}\right)$ and $\mathrm{SN}-\mathrm{O}_{\mathrm{H} 2 \mathrm{O}}-\mathrm{H}_{\mathrm{HBi}}\left(\varphi,,^{\circ}\right)$ angles as a function of hydration level.

\begin{tabular}{|c|c|c|}
\hline $\mathrm{H}_{2} \mathrm{O} / \mathrm{Na}^{+}$ & Average SN-Na-OH2O Angle $\left({ }^{\circ}\right)$ & Average $\mathrm{SN}-\mathrm{O}_{\mathrm{H} 2 \mathrm{O}}-\mathrm{H}_{\mathrm{HBi}}$ Angle $\left(^{\circ}\right)$ \\
\hline 0.6 & 54 & 71 \\
\hline 1 & 82 & 80 \\
\hline 2 & 76 & 73 \\
\hline 2.5 & 79 & 76 \\
\hline 3 & 83 & 78 \\
\hline 3.5 & 81 & 75 \\
\hline 4 & 77 & 69 \\
\hline 4.5 & 75 & 67 \\
\hline 5 & 73 & 61 \\
\hline 5.5 & 71 & 60 \\
\hline 6 & 68 & 60 \\
\hline 6.5 & 66 & 59 \\
\hline 7 & 67 & 58 \\
\hline 7.5 & 67 & 53 \\
\hline 8 & 58 & 52 \\
\hline 8.5 & 57 & 52 \\
\hline 9 & 56 & 52 \\
\hline 9.5 & 55 & 51 \\
\hline 10 & 55 & 53 \\
\hline 11 & 67 & 52 \\
\hline 12 & 63 & 51 \\
\hline
\end{tabular}


Table 2: Diffusion coefficients $\left(\mathrm{m}^{2} / \mathrm{s}\right)$ for $\mathrm{Na}^{+}$ions and $\mathrm{H}_{2} \mathrm{O}$ in the interlayers of the 3, 5.5, and $10 \mathrm{H}_{2} \mathrm{O} / \mathrm{Na}^{+} \mathrm{Na}$-hydroxyhectorite samples.

\begin{tabular}{lll}
\hline Sample & $\mathrm{Na}^{+}$Diffusion $\left(\mathrm{x} 10^{-10} \mathrm{~m}^{2} / \mathrm{s}\right)$ & $\mathrm{H}_{2} \mathrm{O}$ Diffusion $\left(\mathrm{x} 10^{-10} \mathrm{~m}^{2} / \mathrm{s}\right)$ \\
\hline $3 \mathrm{H}_{2} \mathrm{O} / \mathrm{Na}^{+}$ & 0.120 & 0.222 \\
$5.5 \mathrm{H}_{2} \mathrm{O} / \mathrm{Na}^{+}$ & 0.465 & 1.23 \\
$10 \mathrm{H}_{2} \mathrm{O} / \mathrm{Na}^{+}$ & 1.47 & 4.84
\end{tabular}




\section{Figure captions}

Figure 1: Snapshots of Na-hectorite with (a) $0 \mathrm{H}_{2} \mathrm{O} / \mathrm{Na}^{+}$, (b) $0.6 \mathrm{H}_{2} \mathrm{O} / \mathrm{Na}^{+}$, (c) $3 \mathrm{H}_{2} \mathrm{O} / \mathrm{Na}^{+}$, (d) 5.5 $\mathrm{H}_{2} \mathrm{O} / \mathrm{Na}^{+}$, and (e) $10 \mathrm{H}_{2} \mathrm{O} / \mathrm{Na}^{+}$samples viewed parallel to the clay layers down the b-axis. Mg octahedra are yellow, Li octahedra lilac, Si tetrahedra green, O atoms red, $\mathrm{H}$ atoms white, and Na ions cyan.

Figure 2: Schematic diagrams of (a) $\mathrm{SN}-\mathrm{Na}-\mathrm{O}_{\mathrm{H} 2 \mathrm{O}}, \theta$, (b) $\mathrm{SN}-\mathrm{O}_{\mathrm{H} 2 \mathrm{O}}-\mathrm{H}_{\mathrm{HBi}}, \omega$, and (c) $\mathrm{O}_{\mathrm{H} 2 \mathrm{O}}-\mathrm{Na}-$ $\mathrm{O}_{\mathrm{H} 2 \mathrm{O}}, \varphi$, angles, illustrating the geometry of the $\mathrm{Na}^{+}$ion octahedra and the orientation of the $\mathrm{H}_{2} \mathrm{O}$ molecules. The color scheme is the same as Figure 1.

Figure 3: Hydration energy of Na-hectorite versus hydration level $\left(\mathrm{H}_{2} \mathrm{O} / \mathrm{Na}^{+}\right)$, where the dehydrated sample was used as the reference state and values were calculated according to Equation 1. The hydration energy $(-40 \mathrm{~kJ} / \mathrm{mol})$ of bulk water with the SPC potential is shown as the dashed black line.

Figure 3: Hydration energy of Na-hectorite versus hydration level $\left(\mathrm{H}_{2} \mathrm{O} / \mathrm{Na}^{+}\right)$, where the dehydrated sample was used as the reference state and values were calculated according to Equation 1. The hydration energy (-40 kJ/mol) of bulk water with the SPC potential is shown as the dashed black line. 
Figure 4: Atomic density profiles of $\mathrm{Na}^{+}$ions, $\mathrm{O}_{\mathrm{H} 2 \mathrm{O}}$ atoms, and $\mathrm{H}_{\mathrm{H} 2 \mathrm{O}}$ atoms in the interlayers of the Na-hectorite samples. The positions of the basal $\mathrm{O}$ atoms are vertical black dashed lines. $\mathrm{Na}^{+}$ions are green lines, $\mathrm{O}_{\mathrm{H} 2 \mathrm{O}}$ atoms red, and $\mathrm{H}_{\mathrm{H} 2 \mathrm{O}}$ atoms blue.

Figure 5: Interlayer spacing $(\AA)$ versus hydration level $\left(\mathrm{H}_{2} \mathrm{O} / \mathrm{Na}^{+}\right)$for interlayer Na-hectorite samples.

Figure 6: Radial distribution functions (solid lines) and coordination numbers (dashed lines) for (a) $\mathrm{Na}-\mathrm{O}_{\text {MIN }}$ and (b) $\mathrm{Na}-\mathrm{O}_{\mathrm{H} 2 \mathrm{O}}$ for $\mathrm{Na}^{+}$ions in the interlayers of Na-hectorite.

Figure 7: (a) Number of hydrogen bonds per water molecule $\left(\mathrm{HBs} / \mathrm{H}_{2} \mathrm{O}\right)$ as a function of $\mathrm{H}_{2} \mathrm{O} / \mathrm{Na}^{+}$. (b) Fraction of water molecules with given number of $\mathrm{HBs}$ as a function of $\mathrm{H}_{2} \mathrm{O} / \mathrm{Na}^{+}$.

Figure 8: Distribution of (a) $\mathrm{SN}-\mathrm{Na}-\mathrm{O}_{\mathrm{H} 2 \mathrm{O}}\left({ }^{\circ}\right)$ and (b) $\mathrm{SN}-\mathrm{O}_{\mathrm{H} 2 \mathrm{O}}-\mathrm{H}_{\mathrm{HBi}}\left(^{\circ}\right)$ angles as a function of hydration level.

Figure 9: Atomic positions of the (a) $\mathrm{Na}^{+}$ions, (b) $\mathrm{O}_{\mathrm{H} 2 \mathrm{O}}$ atoms, and (c) $\mathrm{H}_{\mathrm{H} 2 \mathrm{O}}$ atoms in the 0 $\mathrm{H}_{2} \mathrm{O} / \mathrm{Na}^{+}$, $0.6 \mathrm{H}_{2} \mathrm{O} / \mathrm{Na}^{+}$, $3 \mathrm{H} 2 \mathrm{O} / \mathrm{Na}^{+}$, $5.5 \mathrm{H}_{2} \mathrm{O} / \mathrm{Na}^{+}$, and $10 \mathrm{H}_{2} \mathrm{O} / \mathrm{Na}^{+}$samples. Si atoms are closed circles, $\mathrm{O}_{\text {MIN }}$ atoms open circles, $\mathrm{Na}^{+}$ions turquoise plus signs, $\mathrm{O}_{\mathrm{H} 2 \mathrm{O}}$ atoms red plus signs, and $\mathrm{H}_{\mathrm{H} 2 \mathrm{O}}$ atoms blue plus signs. Solid and dashed lines mark $\mathrm{Si}-\mathrm{O}$ hexagonal rings of the top and bottom sides of the interlayer, respectively. 
Figure 10: Free energies for the $\mathrm{SN}-\mathrm{Na}-\mathrm{O}_{\mathrm{H} 2 \mathrm{O}}$ angles, $\theta$, from metadynamics calculations, showing the energy minima (kJ/mol) for the (a) $1 \mathrm{WL}$ and (b) $2 \mathrm{WL}$ samples.

Figure 11: Free energies for the $\mathrm{O}_{\mathrm{H} 2 \mathrm{O}}-\mathrm{Na}-\mathrm{O}_{\mathrm{H} 2 \mathrm{O}}$ angles, $\varphi$, from metadynamics calculations, showing the energy minima ( $\mathrm{kJ} / \mathrm{mol})$ for the (a) $1 \mathrm{WL}$ and (b) $2 \mathrm{WL}$ samples. 
Figure 1: Snapshots of Na-hectorite with (a) $0 \mathrm{H}_{2} \mathrm{O} / \mathrm{Na}^{+}$, (b) $0.6 \mathrm{H}_{2} \mathrm{O} / \mathrm{Na}^{+}$, (c) $3 \mathrm{H}_{2} \mathrm{O} / \mathrm{Na}^{+}$, (d) $5.5 \mathrm{H}_{2} \mathrm{O} / \mathrm{Na}^{+}$, and (e) $10 \mathrm{H} 2 \mathrm{O} / \mathrm{Na}^{+}$samples viewed parallel to the clay layers down the $b$-axis. Mg octahedra are yellow, Li octahedra lilac, Si tetrahedra green, $\mathrm{O}$ atoms red, $\mathrm{H}$ atoms white, and Na ions cyan.

(a)

(b)

(c)

(d)

(e)

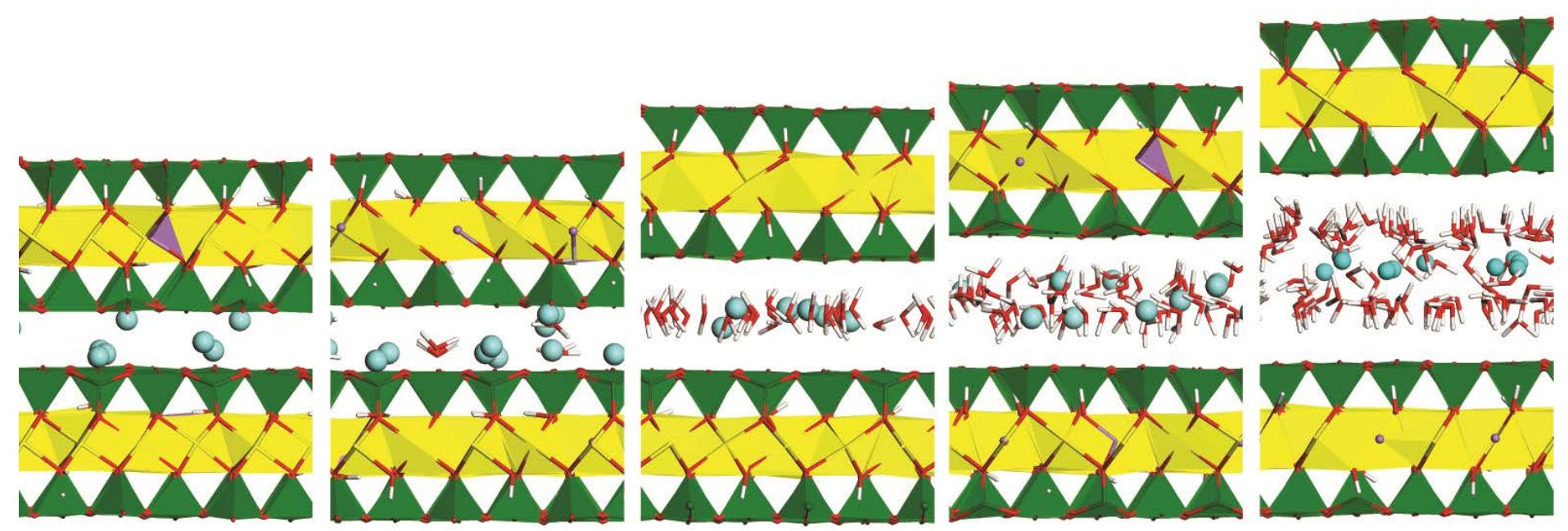




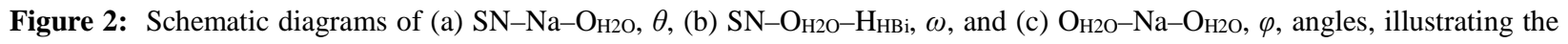
geometry of the $\mathrm{Na}^{+}$ion octahedra and the orientation of the $\mathrm{H}_{2} \mathrm{O}$ molecules. The color scheme is the same as Figure 1.

(a)

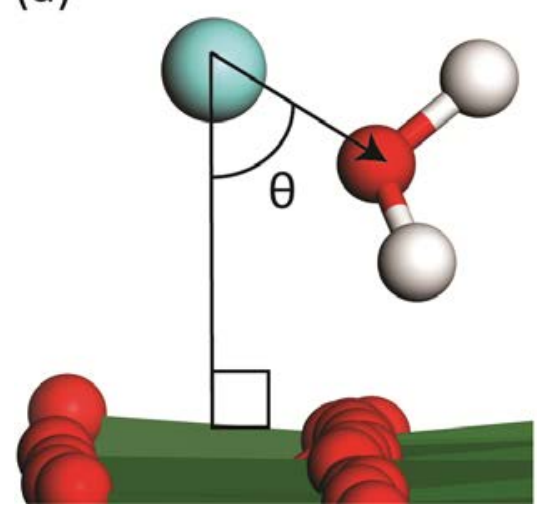

(b)

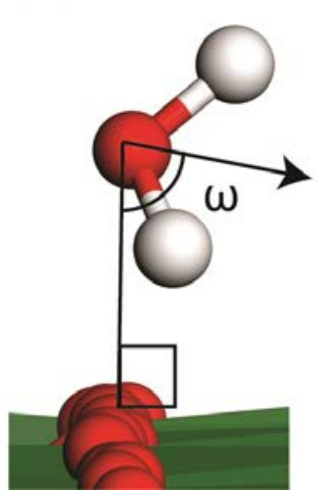

(c)

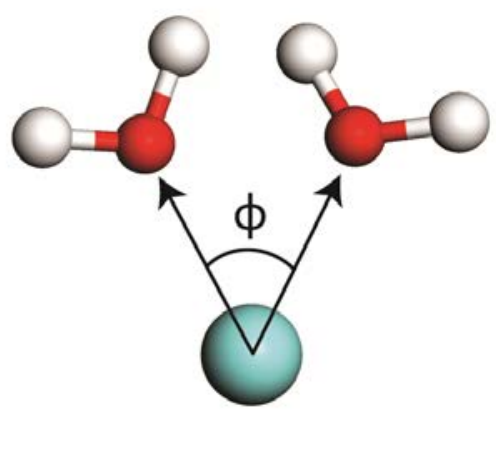


Figure 3: Hydration energy of Na-hectorite versus hydration level $\left(\mathrm{H}_{2} \mathrm{O} / \mathrm{Na}^{+}\right)$, where the dehydrated sample was used as the reference state and values were calculated according to Equation 1 . The hydration energy $(-40 \mathrm{~kJ} / \mathrm{mol})$ of bulk water with the SPC potential is shown as the dashed black line.

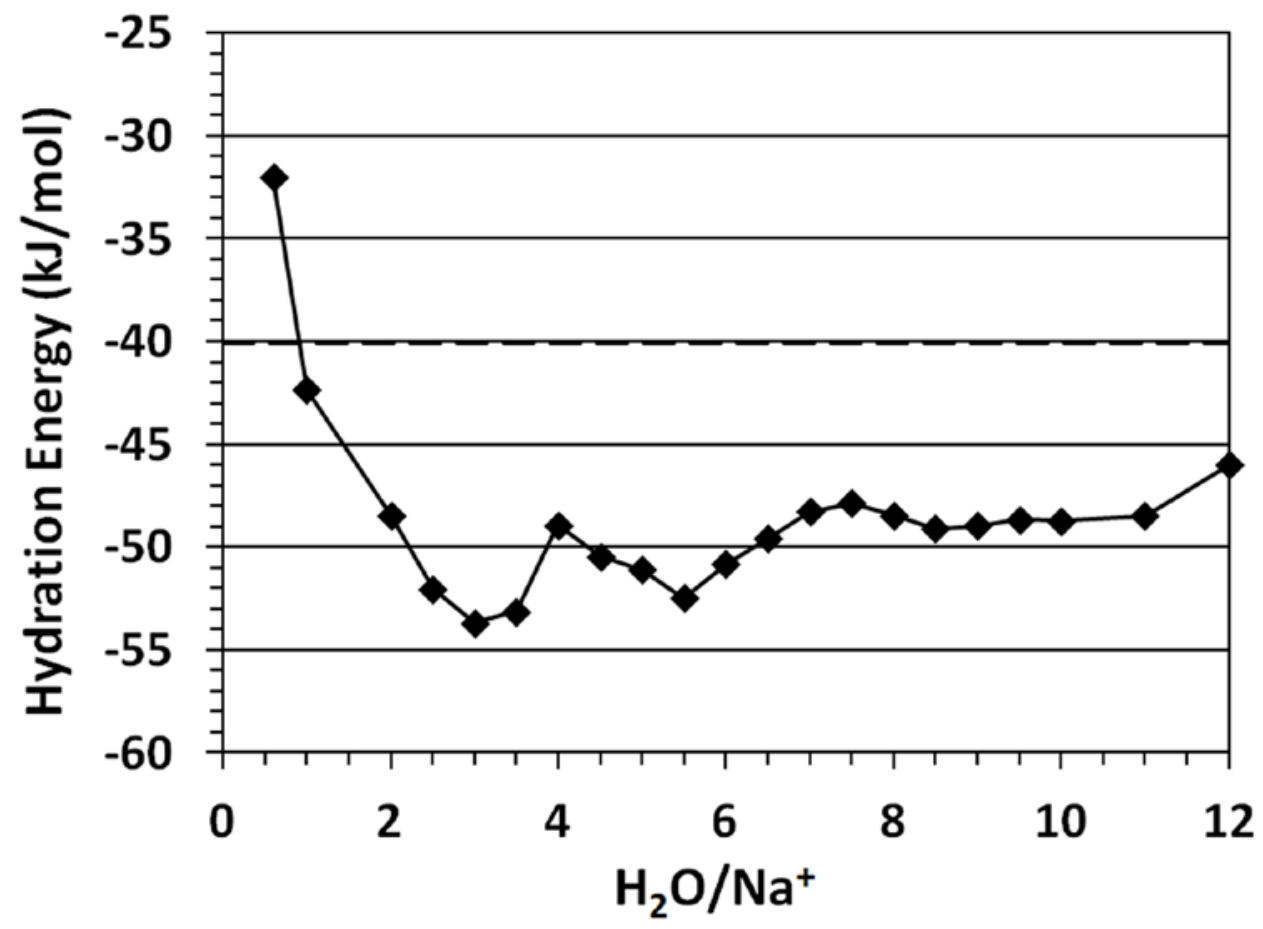




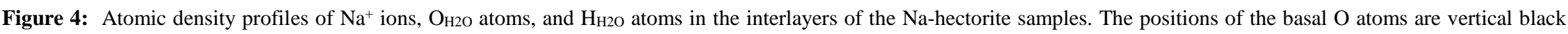
dashed lines. $\mathrm{Na}^{+}$ions are green lines, Онго atoms red, and $\mathrm{H}_{\mathrm{H} 2 \mathrm{O}}$ atoms blue.
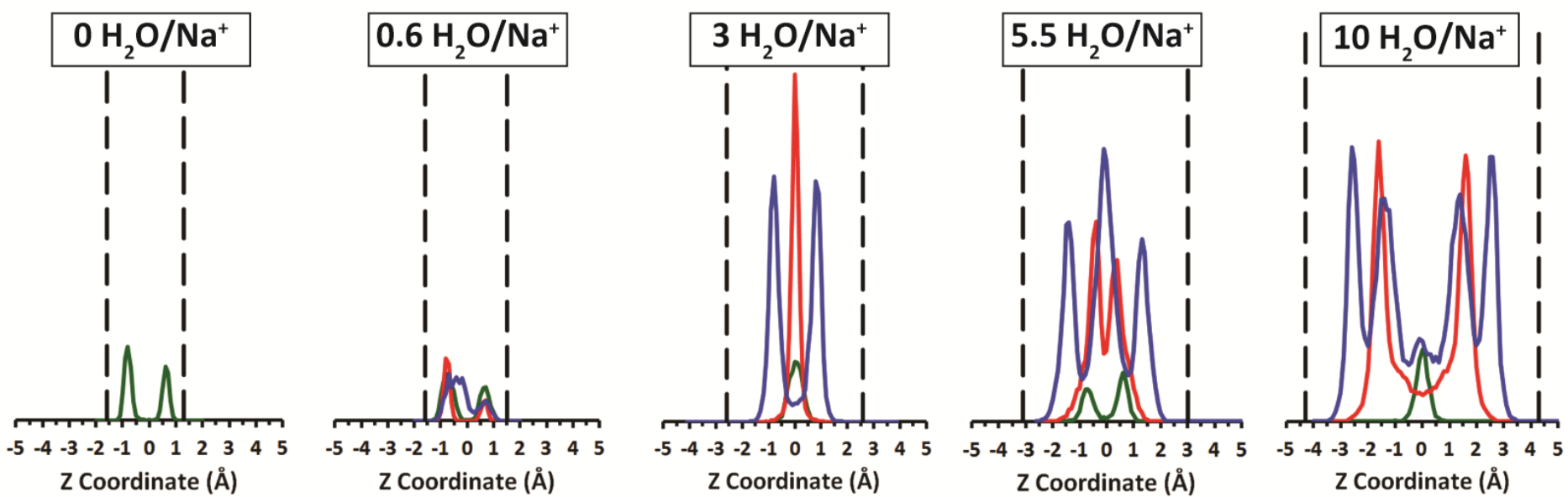
Figure 5: Interlayer spacing $(\AA)$ versus hydration level $\left(\mathrm{H}_{2} \mathrm{O} / \mathrm{Na}^{+}\right)$for interlayer Na-hectorite samples.

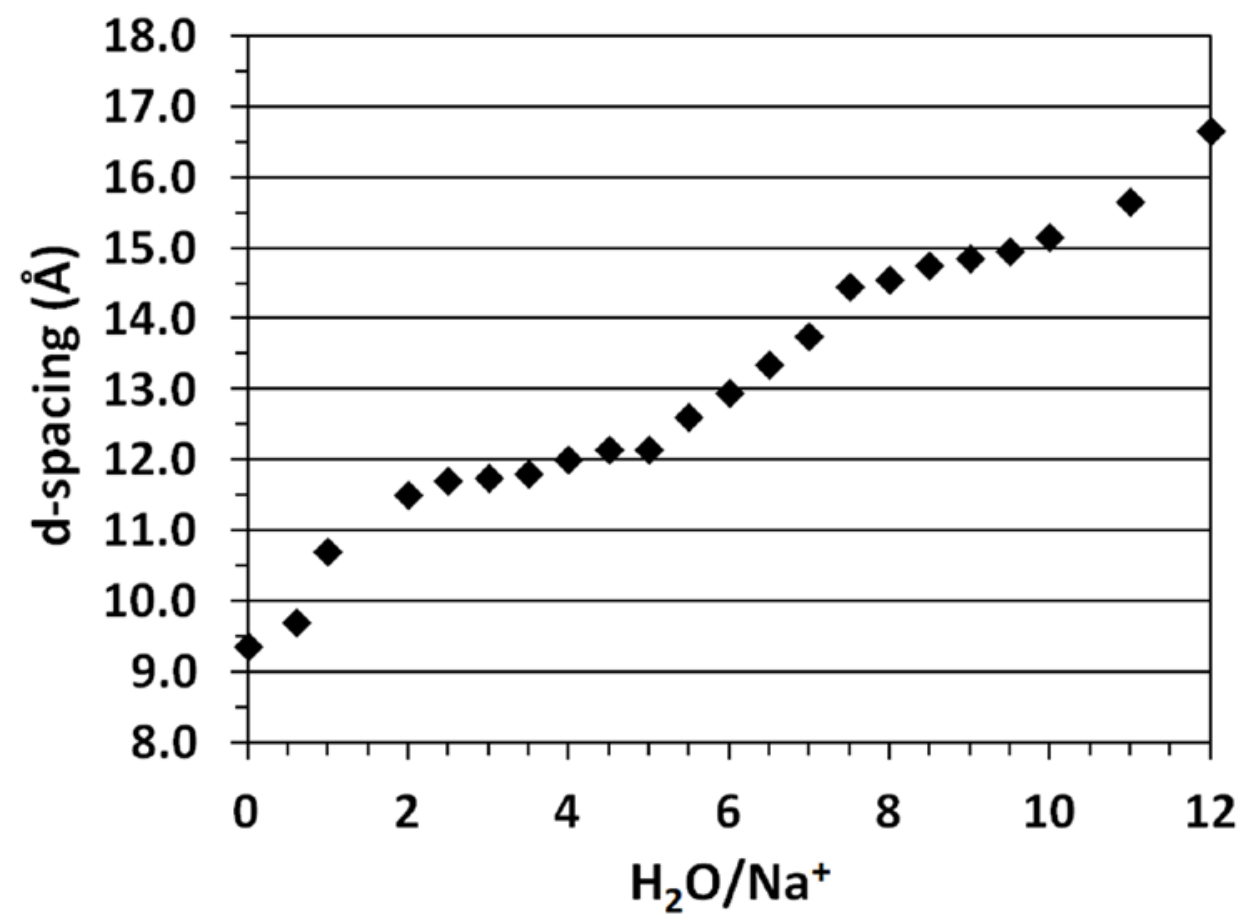


Figure 6: Radial distribution functions (solid lines) and coordination numbers (dashed lines) for (a) Na-OMIN and (b) Na-OH2O for $\mathrm{Na}^{+}$ions in the interlayers of Na-hectorite.

(a)
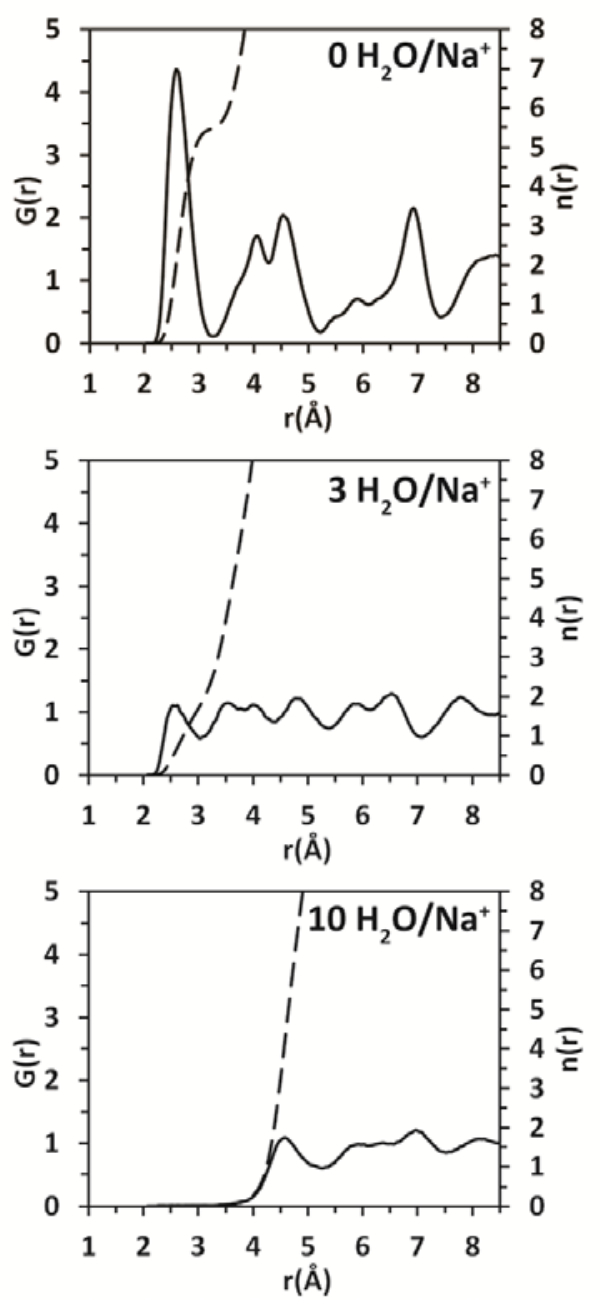

$$
\mathrm{Na}^{+}-\mathrm{O}_{\mathrm{MIN}}
$$
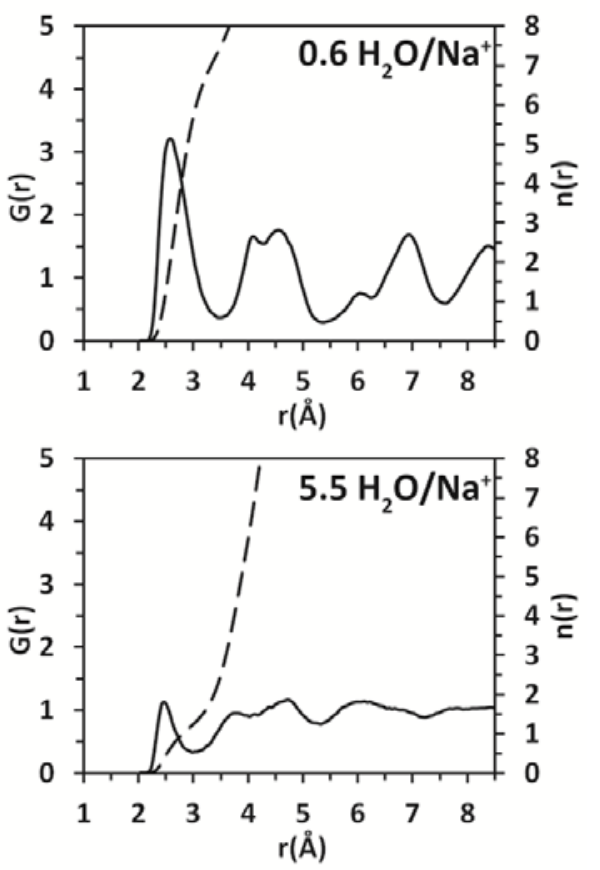
(b)
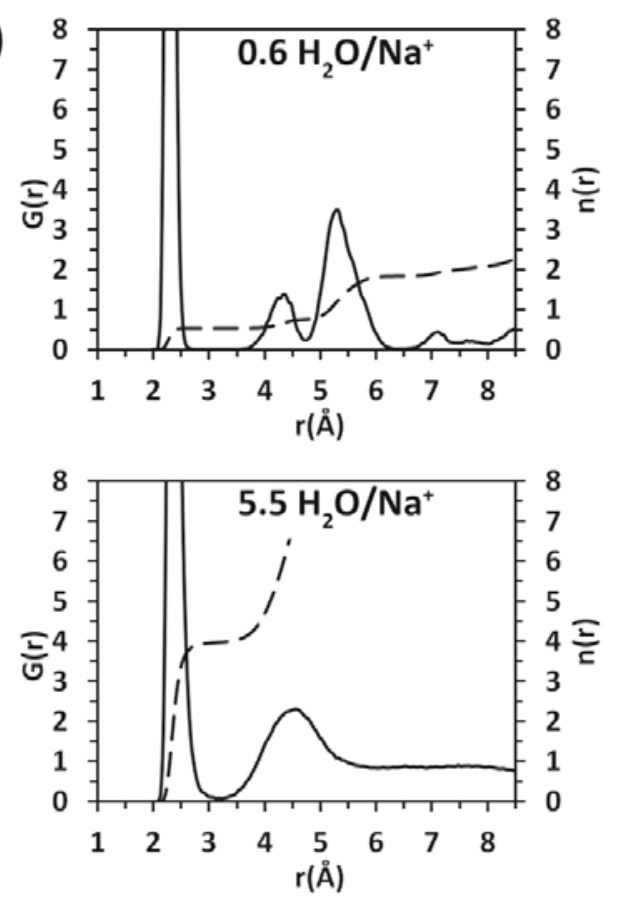

$\mathrm{Na}^{+}-\mathrm{O}_{\mathrm{H} 2 \mathrm{O}}$
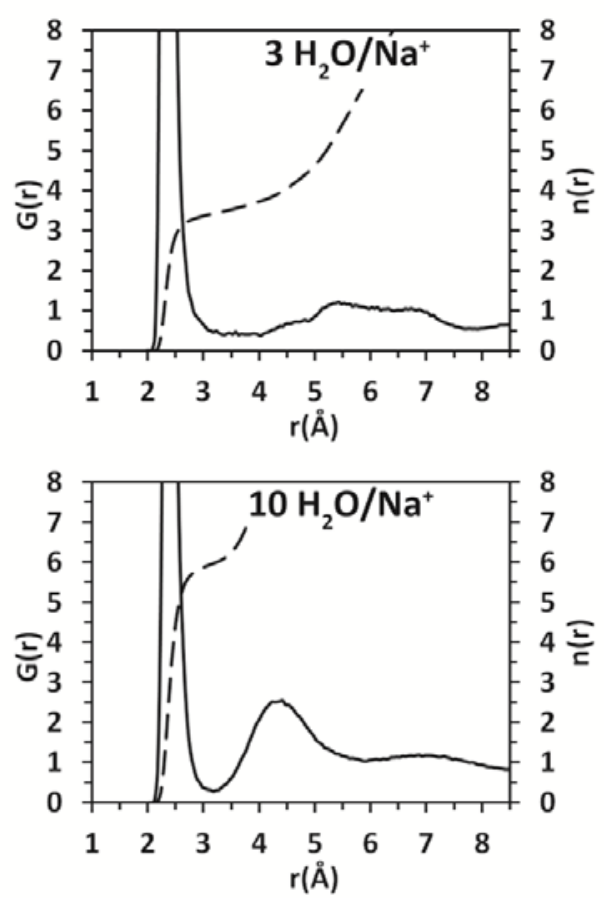
Figure 7: (a) Number of hydrogen bonds per water molecule $\left(\mathrm{HBs} / \mathrm{H}_{2} \mathrm{O}\right.$ ) as a function of $\mathrm{H}_{2} \mathrm{O} / \mathrm{Na}^{+}$. (b) Fraction of water molecules with given number of $\mathrm{HBs}$ as a function of $\mathrm{H}_{2} \mathrm{O} / \mathrm{Na}^{+}$.

(a)

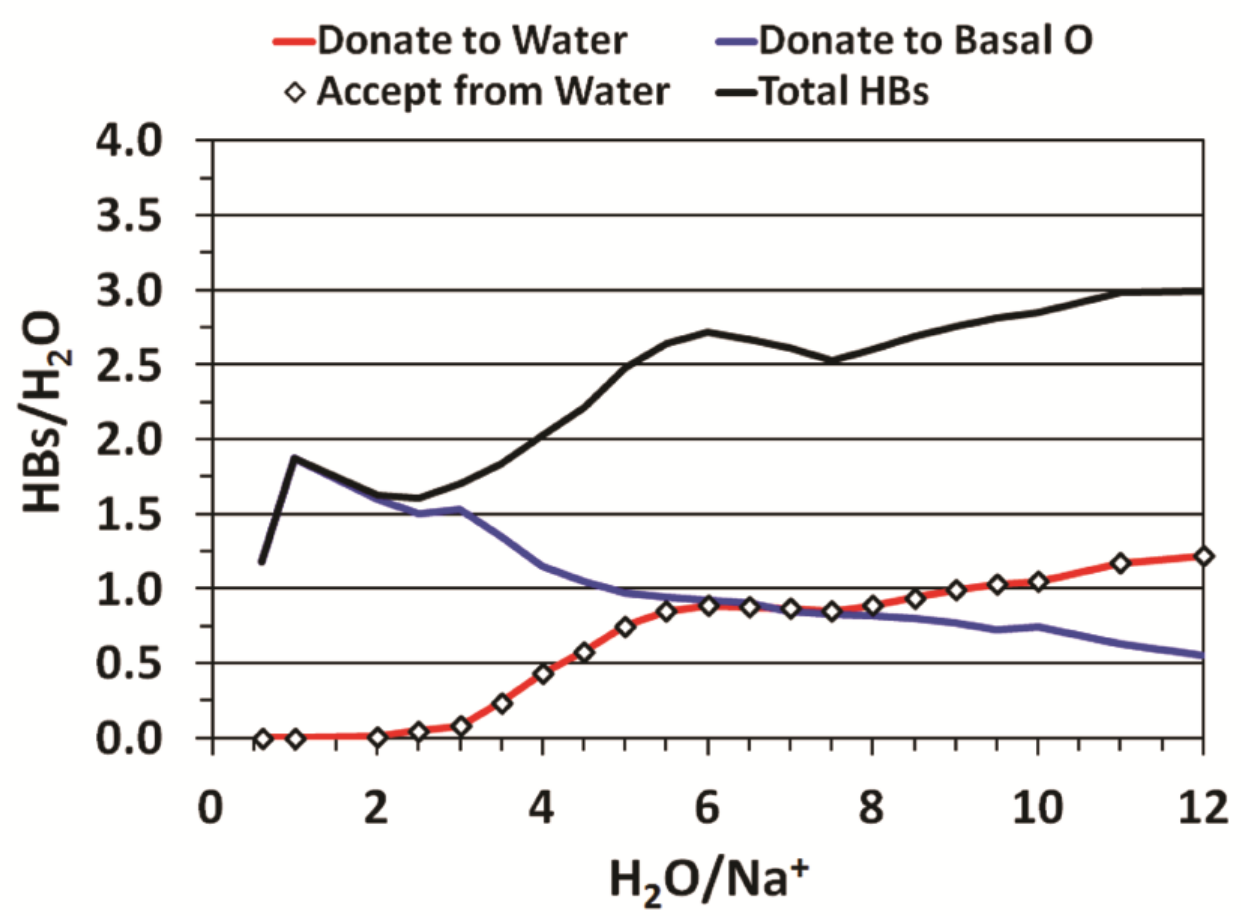

(b)

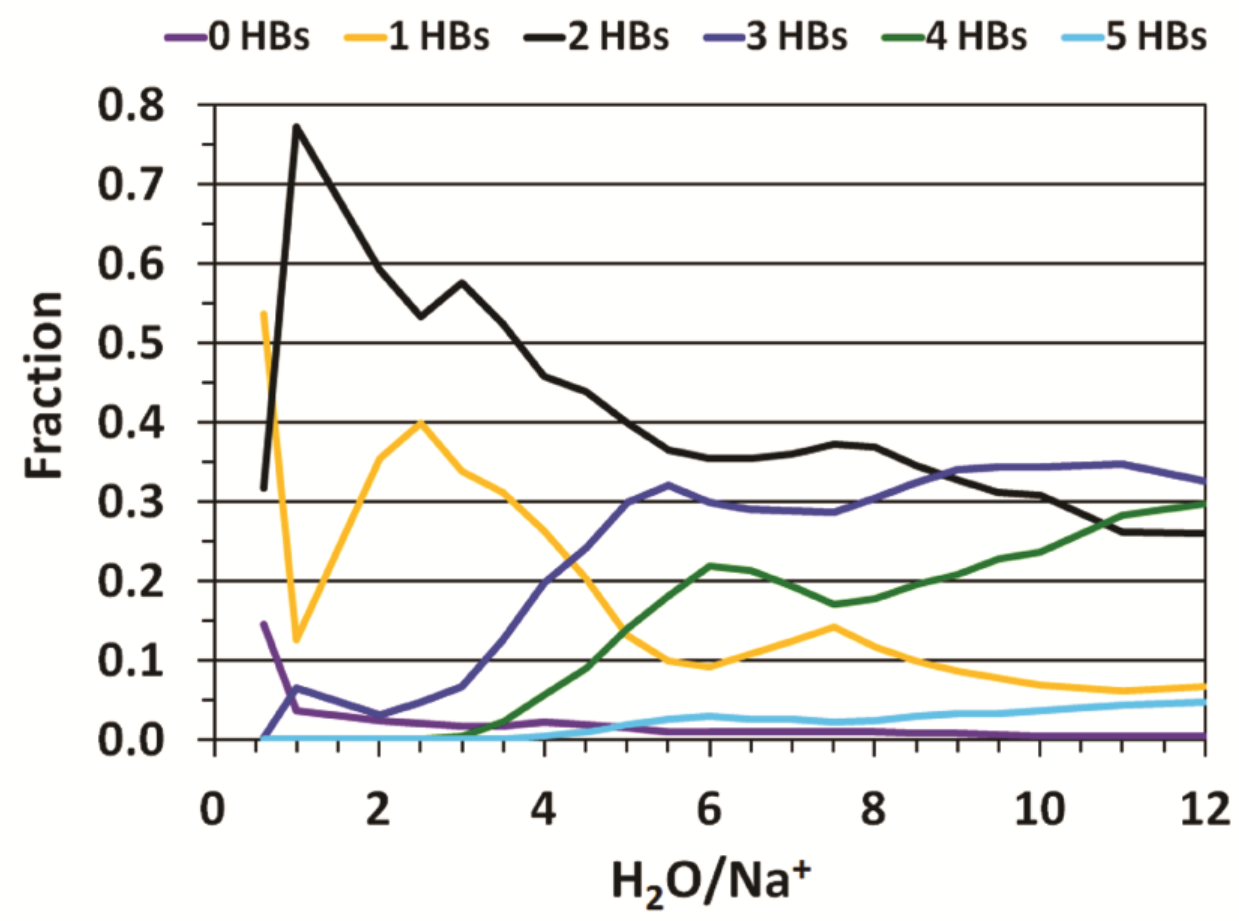


Figure 8: Distribution of (a) $\mathrm{SN}-\mathrm{Na}-\mathrm{O}_{\mathrm{H} 2 \mathrm{O}}\left({ }^{\circ}\right)$ and (b) $\mathrm{SN}-\mathrm{O}_{\mathrm{H} 2 \mathrm{O}}-\mathrm{H}_{\mathrm{HBi}}\left({ }^{\circ}\right)$ angles as a function of hydration level.

(a)

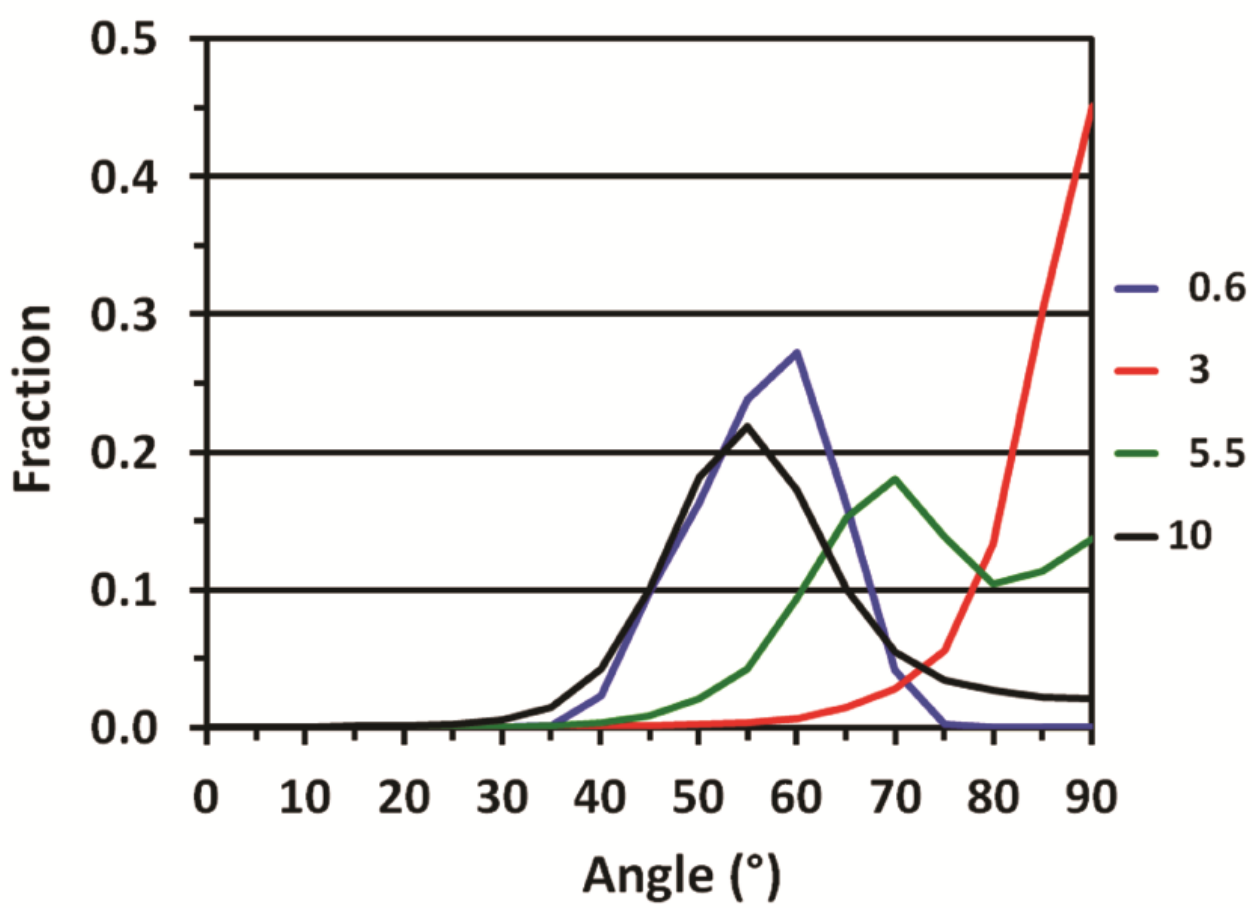

(b)

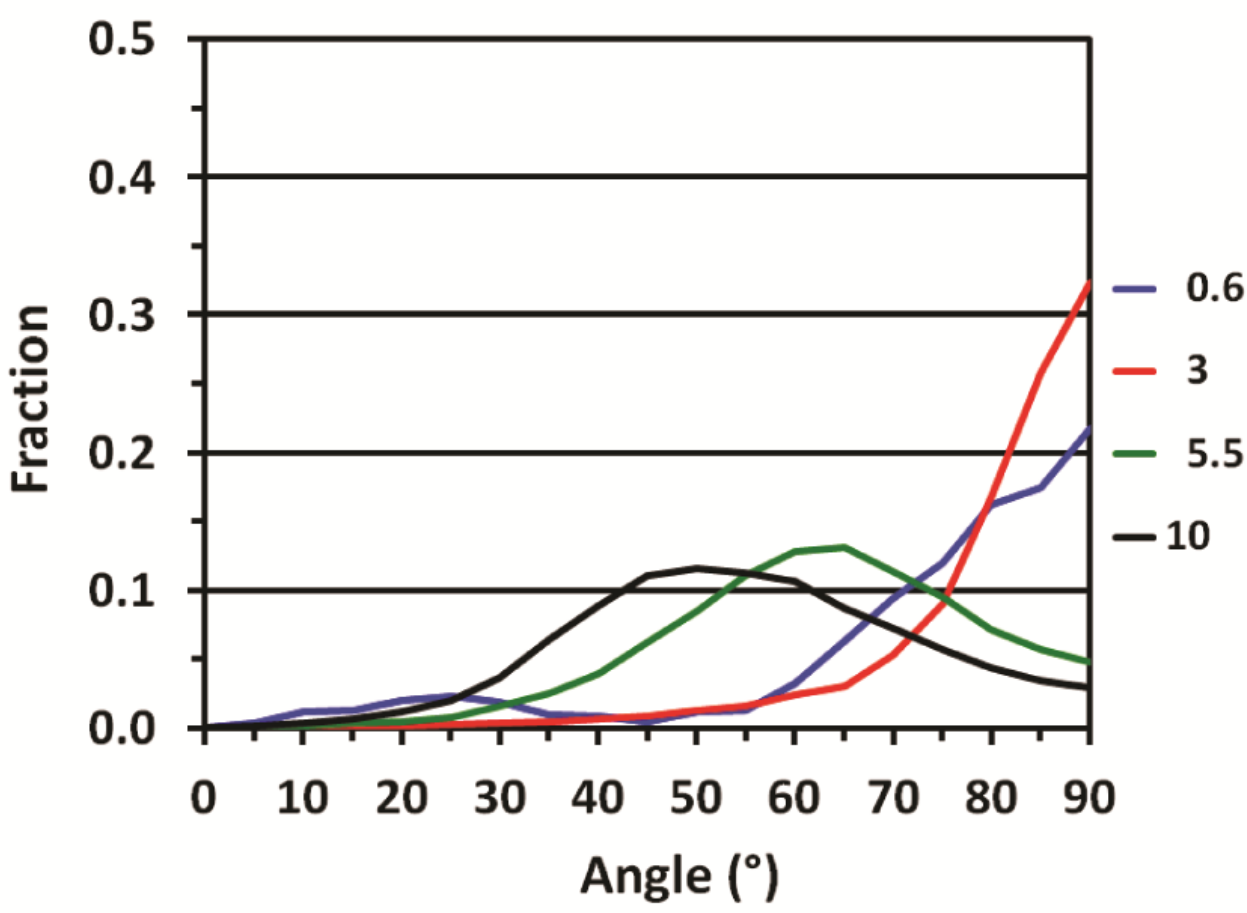


Figure 9: Atomic positions of the (a) $\mathrm{Na}^{+}$ions, (b) $\mathrm{OH} 2 \mathrm{O}$ atoms, and (c) $\mathrm{H}_{2} \mathrm{O}$ atoms in the $0 \mathrm{H} 2 \mathrm{O} / \mathrm{Na}^{+}, 0.6 \mathrm{H}_{2} \mathrm{O} / \mathrm{Na}^{+}, 3 \mathrm{H} 2 \mathrm{O} / \mathrm{Na}^{+}$, $5.5 \mathrm{H}_{2} \mathrm{O} / \mathrm{Na}^{+}$, and $10 \mathrm{H}_{2} \mathrm{O} / \mathrm{Na}^{+}$samples. Si atoms are closed circles, OMin atoms open circles, $\mathrm{Na}^{+}$ions turquoise plus signs, OH2O atoms red plus signs, and $\mathrm{H}_{\mathrm{H} 2 \mathrm{O}}$ atoms blue plus signs. Solid and dashed lines mark $\mathrm{Si}-\mathrm{O}$ hexagonal rings of the top and bottom sides of the interlayer, respectively.

(a)
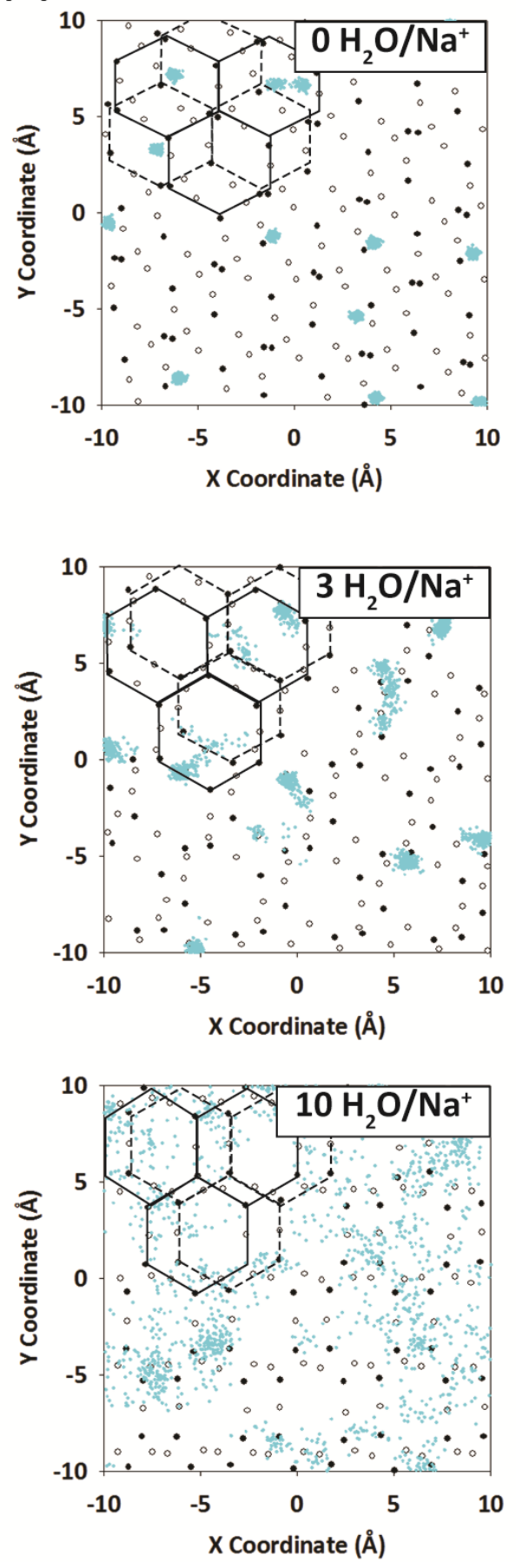

$\mathrm{Na}^{+}$
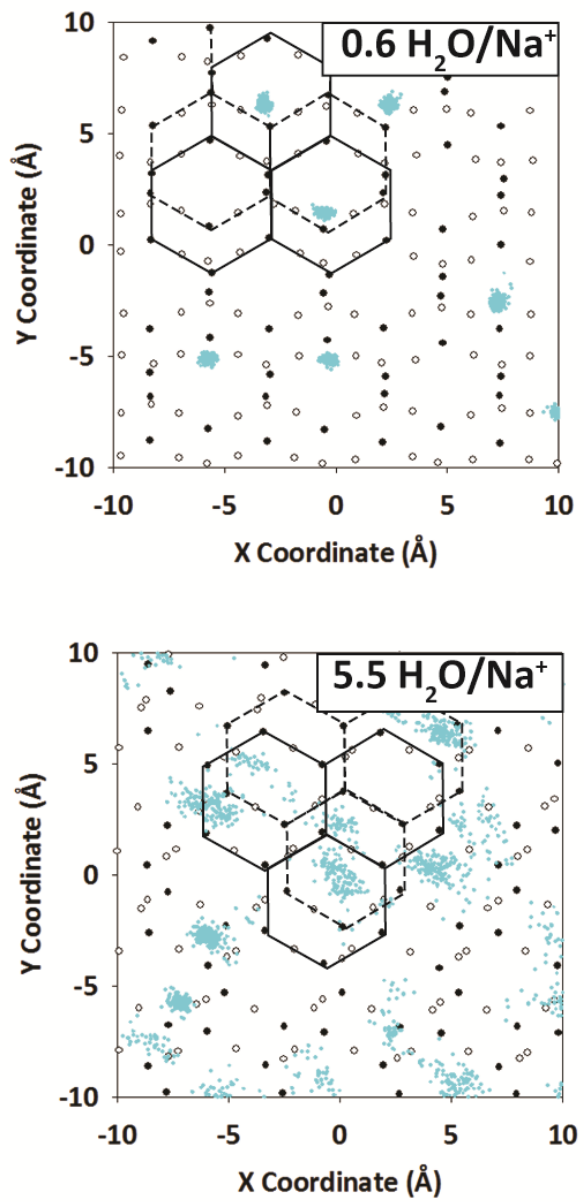
(b)

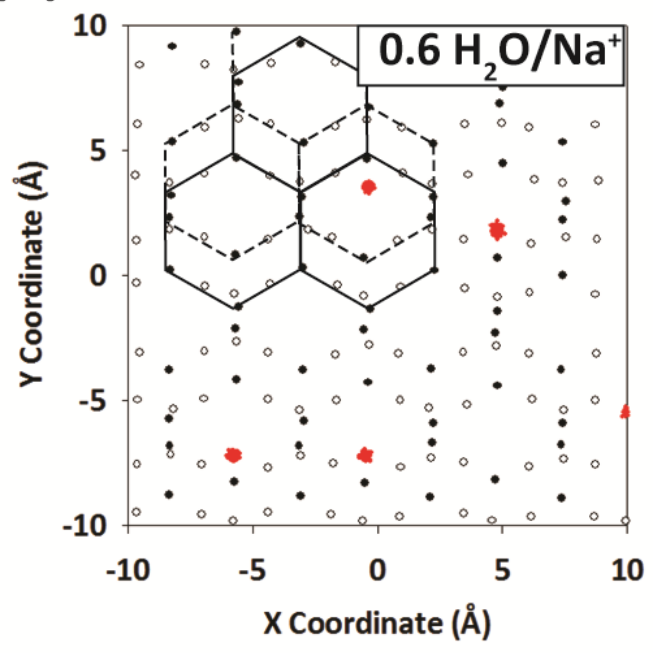

$\mathrm{O}_{\mathrm{H} 2 \mathrm{O}}$
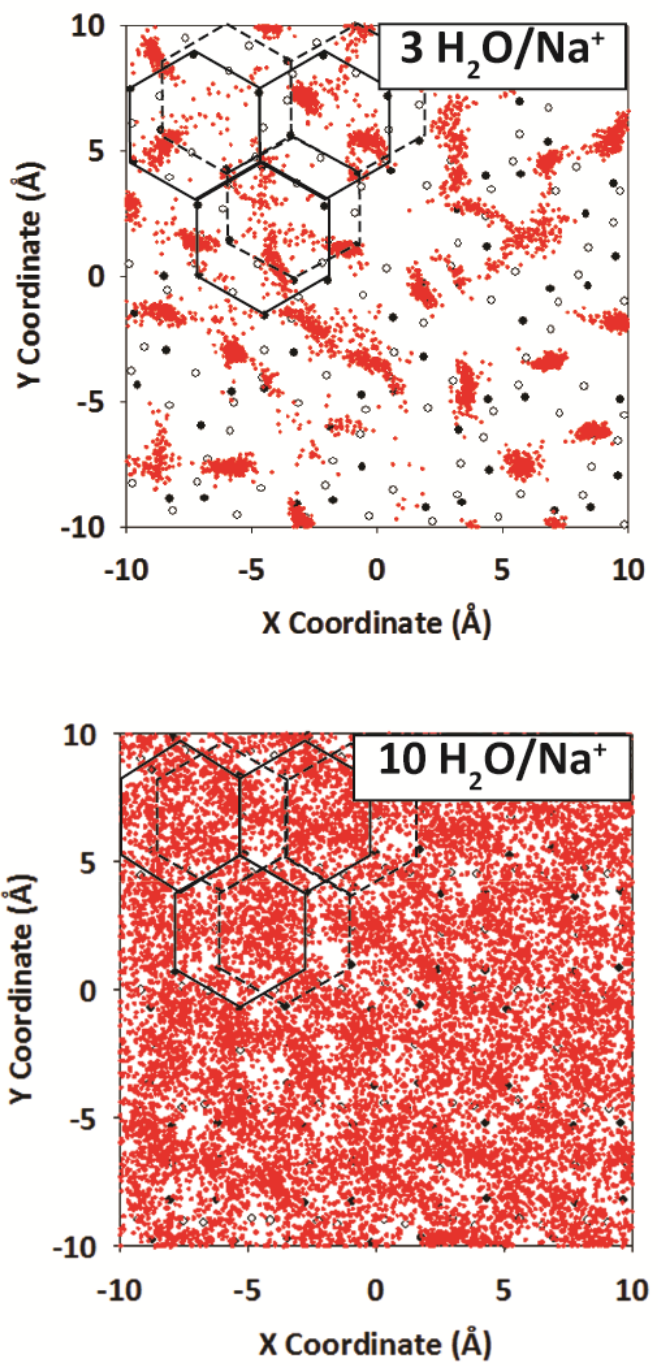

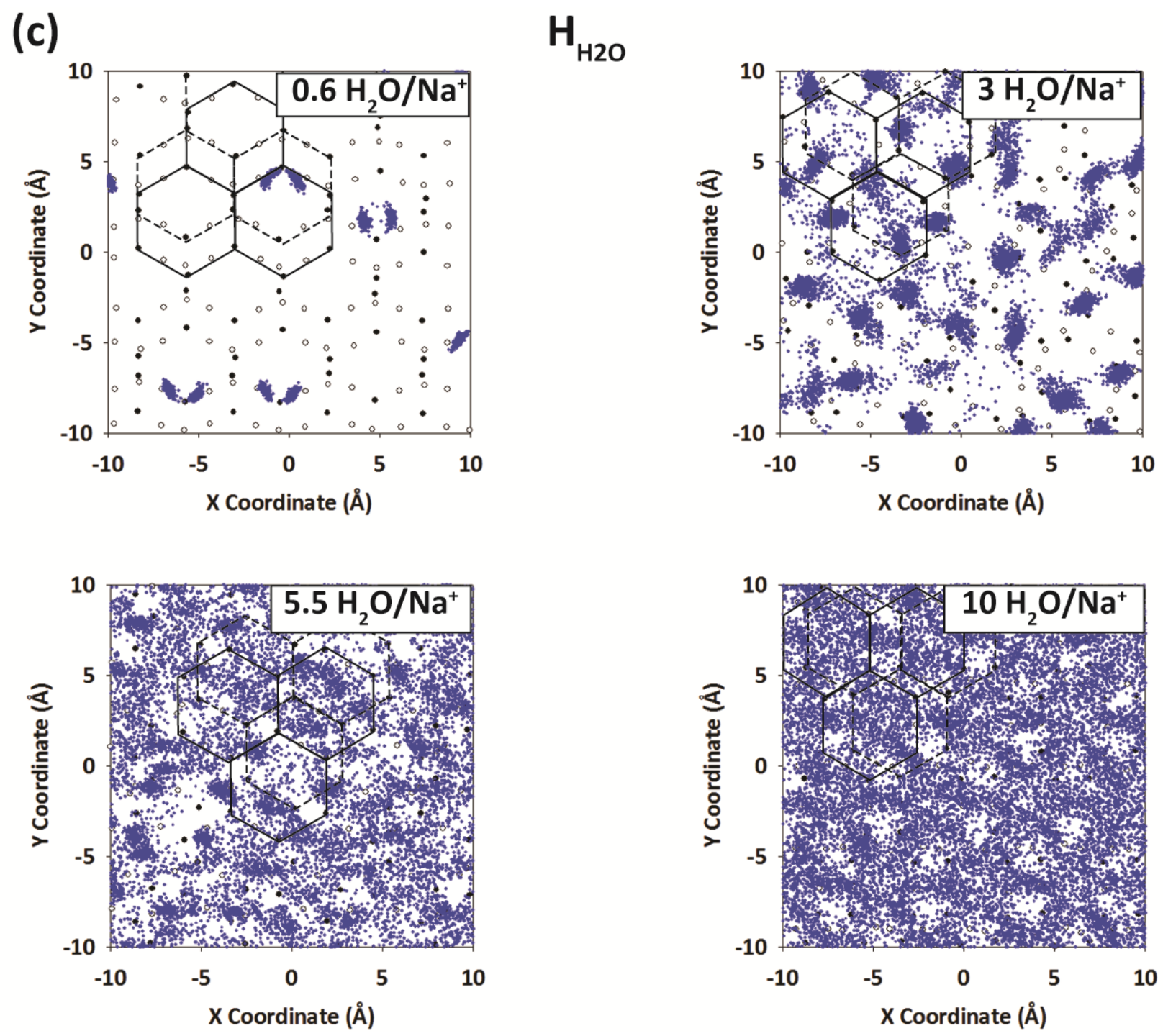
Figure 10: Free energies for the $\mathrm{SN}-\mathrm{Na}-\mathrm{O}$ но angles, $\theta$, from metadynamics calculations, showing the energy minima $(\mathrm{kJ} / \mathrm{mol})$ for the (a) $1 \mathrm{WL}$ and (b) $2 \mathrm{WL}$ samples.

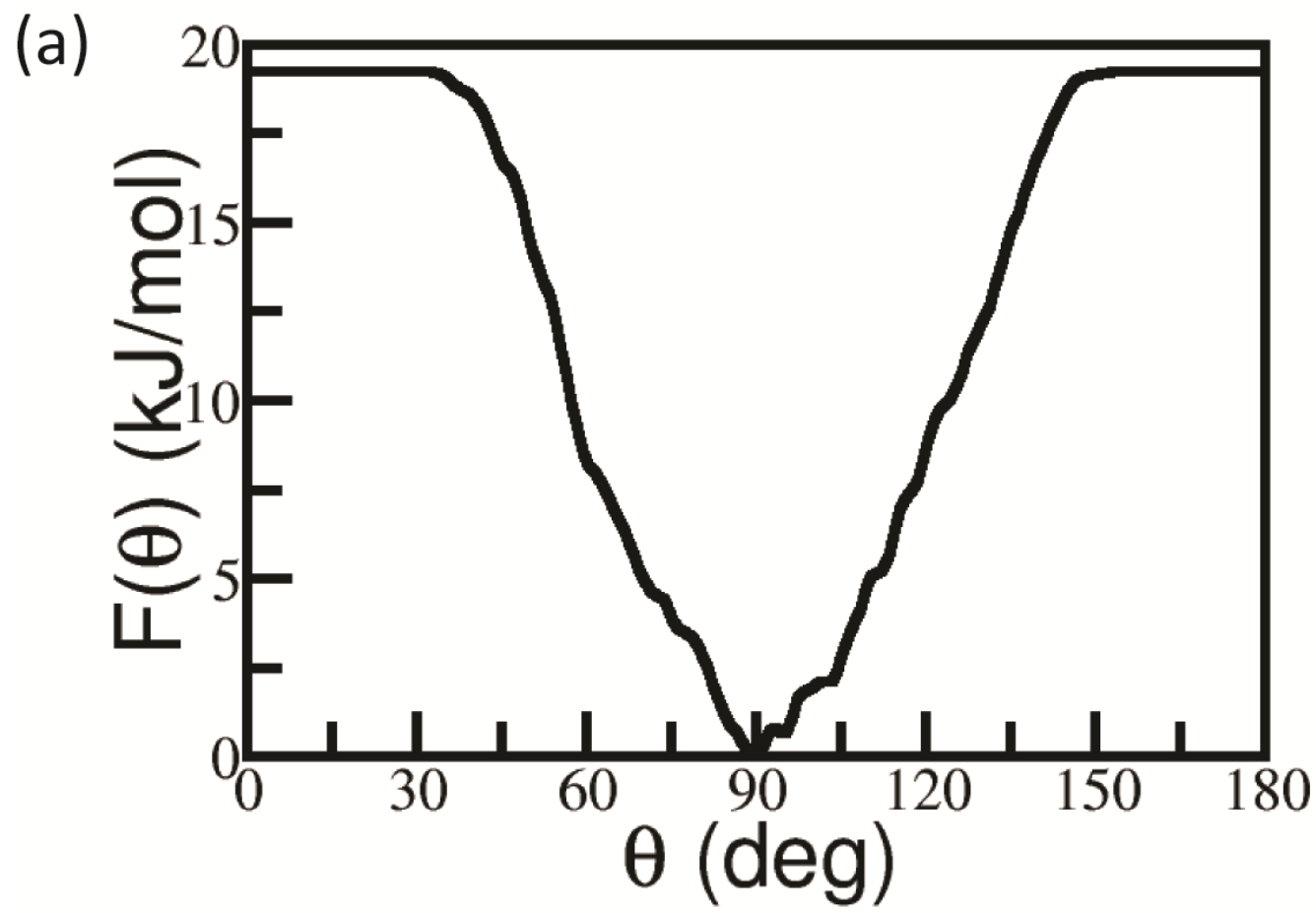

(b)

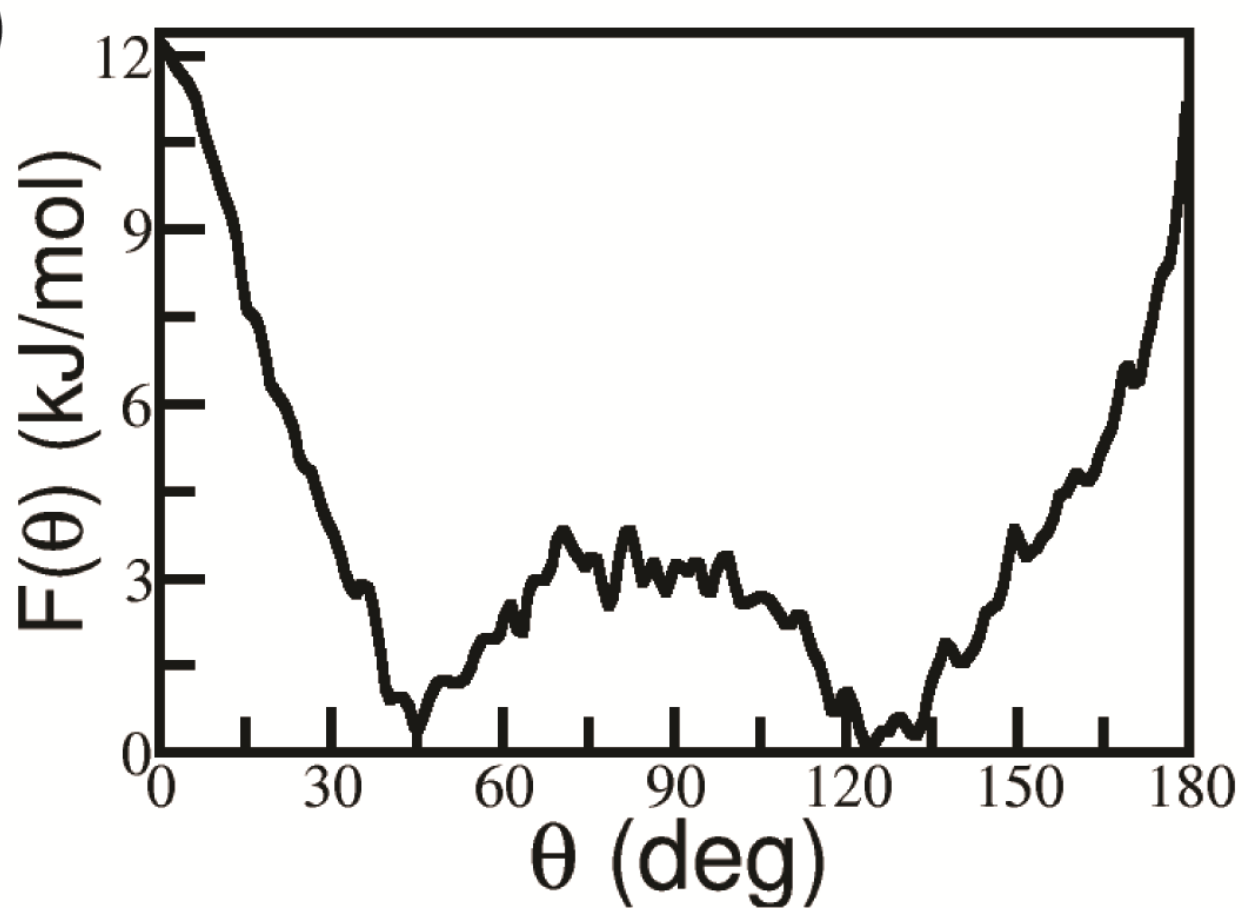


Figure 11: Free energies for the $\mathrm{O}_{2} \mathrm{O}-\mathrm{Na}-\mathrm{O} 2 \mathrm{O}$ angles, $\varphi$, from metadynamics calculations, showing the energy minima $(\mathrm{kJ} / \mathrm{mol})$ for the (a) $1 \mathrm{WL}$ and (b) $2 \mathrm{WL}$ samples.

(a)

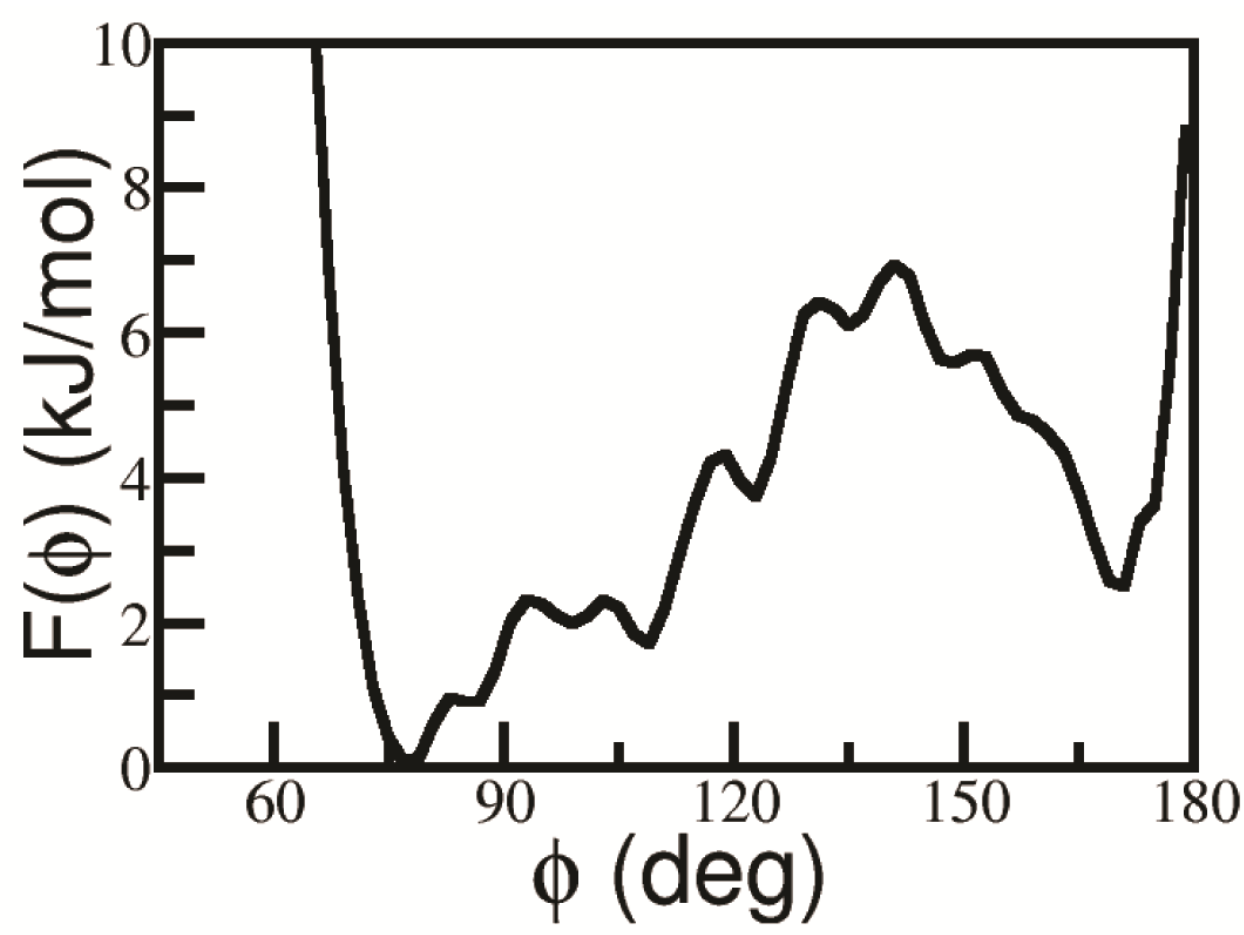

(b)

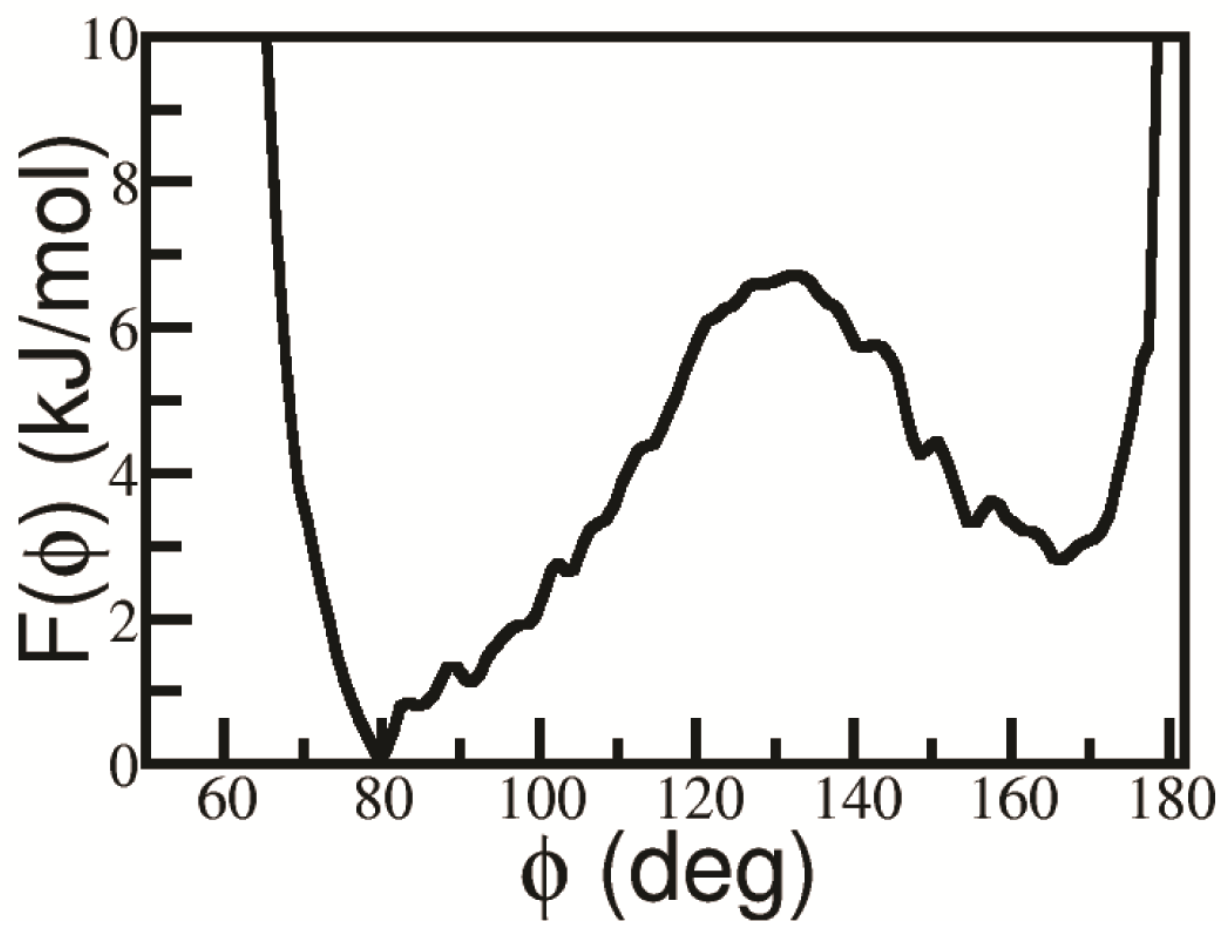

